\title{
A political sociology of empire: Mughal historians on the making of Mughal paramountcy
}

\author{
Gagan D. S. Sood \\ Department of International History, The London School of Economics and Political \\ Science, London, United Kingdom \\ Email: g.sood1@lse.ac.uk
}

(Received 26 October 2020; revised 1 July 2021; accepted 2 July 2021)

\begin{abstract}
In this article, Mughal understandings of their own past are reconstructed from the standpoint of Mughal paramountcy in around 1700. That was the moment of the empire's greatest territorial reach, when it knew no peer nor threat. To reconstruct contemporary understandings of how this situation came about, histories of the Mughal empire composed by governing officials of the time are analysed using a novel approach rooted in a particular distinction between constants and contingencies. These understandings allow us to recapture the political sociology of empire as apprehended by the Mughal elites. The article's findings are of value for two reasons. Narrowly construed, they help fill a lacuna in mainstream views on Mughal historiography, traditionally dominated by Akbar and his reign, and imbued with the logic of decline (and of its corollary, the transition to colonialism). More broadly, because of the weight accorded to knowledge of the past in the formation of Mughal ruling elites, the findings provide fresh insights into the cognitive framework within which these elites operated at a moment recognized as highly significant then, and in retrospect.
\end{abstract}

Keywords: Mughal empire; political sociology; elite loyalty; imperial unity; Mughal historiography; Indo-Persian historiography; salțanat; mamālik-i mahrūsah

This article is based wholly on Persian sources. All transliterations from them follow the IJMES system. Because of the importance accorded to concepts used by Mughal contemporaries, key Persian terms which cannot be unambiguously or easily translated into English are written out as transliterations in the main text. Their meanings in the period are given in the appended glossary. Also appended for reference is a table stating the birth, death, and regnal dates of the principal rulers mentioned in the article.

(C) The Author(s), 2021. Published by Cambridge University Press. This is an Open Access article, distributed under the terms of the Creative Commons Attribution-NonCommercial-NoDerivatives licence (http://creative commons.org/licenses/by-nc-nd/4.0/), which permits non-commercial re-use, distribution, and reproduction in any medium, provided that no alterations are made and the original article is properly cited. The written permission of Cambridge University Press must be obtained prior to any commercial use and/or adaptation of the article. 


\section{Introduction}

Knowledge of the past was important in the formation of a leading official or prospective ruler in the Mughal empire. As 'Abd al-Haqq Dihlavi, an influential scholar and one-time courtier, wrote in the early seventeenth century:

All created beings need reason, and reason needs experience, and for experiences a long period is necessary and a long life and free time and ease of mind. So, when the sages of the world saw that the length of the transitory life does not suffice for that, they devised a remedy and made a plan to constrain this loss and compensate for this privation. They recorded in books and chronicles the news of the rulers and the circumstances of the nobles and ministers and the words of the scholars and philosophers. And they put down in writing the stories and annals of those who lived in the past for the benefit of those to come [and] to rouse the heedless ones ... That which is not acquired concerning the properties of the world and the properties of the time and their people through experiences and choices over the length of a long life and after undertaking long and distant journeys and associating with different sorts of people and measuring their actions and works-in a short time [all this] is acquired [through the aforesaid writings]. The wise man must not be deprived of the share of lessons and expertise, and must balance it up for himself and his own circumstances. ${ }^{1}$

Thus history as distilled collective experience framed the expectations of contemporary Mughal decision-makers. It helped them discern the present state of affairs and the possible consequences of current and future policies. ${ }^{2}$ It helped them deal with the challenges they faced as the empire's ruling elites and to improve its sovereign governance in accord with prevailing ideals. ${ }^{3}$ Therefore, to comprehend the actions of Mughal decision-makers we must take into account their understanding of history. Rulers and regimes from the distant past loom large in this. But so does the past of their own time and place, of their own dynasty and empire. The focus of this article is on the latter. It gives an analysis of histories composed by Mughal officials at the moment of their empire's greatest territorial reach-around 1700, when Mughal paramountcy knew no peer nor threat-in order to reconstruct

1 Shaikh 'Abd al-Haqq Muhaddis Dihlavī, Risālah-i nūriyyah sulțāniyyah [in Persian] (introduced, edited and annotated by Muhammad Salim Akhtar) (Islamabad, 1985), p. 47 (my translation).

2 On the relationship between past experiences and future expectations, see Reinhart Koselleck, "'Space of experience" and "horizon of expectation": Two historical categories', in his Futures Past: On the Semantics of Historical Time (New York, 2004), pp. 255-275.

3 These ideals were discussed by contemporaries under the rubric of akhlāq ('ethics') and nașihat ('advice'). See Muzaffar Alam, 'Sharī'a, akhlāq and governance', in his The Languages of Political Islam in India, 1200-1800 (Chicago, IL, 2004), pp. 26-80; Saïd Amir Arjomand, 'The salience of political ethic in the spread of Persianate Islam', Journal of Persianate Studies 1:1 (2008), pp. 5-29; Louise Marlow, 'Advice and advice literature', Encyclopaedia of Islam, THREE, 1 (2007), pp. 34-58. 
orthodox interpretations of the Mughal past dispersed among the ruling elites. In so doing, we recapture their political sociology of empire as they conceived it. This has not been done before.

There exists a wealth of scholarship on Mughal and, more generally, Indo-Persian historiography. ${ }^{4}$ It was one of the earliest subjects to be studied by Western Orientalists, and interest in it has been sustained ever since. There are, however, major gaps in what has been covered by modern scholars. These gaps are not accidental nor are they due merely to a dearth of specialists. Rather, they result from choices shaped by the intellectual approaches and goals which have prevailed until recently-and, in several respects, still prevail. ${ }^{5}$ Most pertinently for this article, the choices mean that histories composed in Akbar's reign (1556-1605) and in the period of the Company Raj (circa 1750-1850) have been stressed at the expense of those composed over the long stretch of time in-between. The subsequent gaps in the subject's coverage have allowed widespread views on the development of historiography in the Mughal empire and its 'successor' regimes to persist unquestioned and unsubstantiated. On a closer look, many of these are vested in a combination of 'unwarranted ethnocentrisms, anachronisms, essentialisations and path dependencies'. ${ }^{6}$

This article seeks to remedy the situation in a particular way. It analyses histories composed at a moment in the trajectory of the Mughal empire-a moment of sovereign hegemony of unprecedented scope, straddling the end of the seventeenth century and the turn of the eighteenth-which was recognized as highly significant then, and in retrospect. These histories, which (as discussed below) have hitherto never been systematically examined, were authored by a spectrum of current or former Mughal officials at that very moment. Though the histories are of different types, all of them give an account of the Mughal past from its origins up to at least the start of Aurangzeb's reign (1658-1707). They have been analysed here to determine their authors' interpretations of the Mughal past. These interpretations are then juxtaposed with mainstream scholarly views today on Mughal

4 This is surveyed in Jagtar Singh Grewal, Muslim Rule in India: The Assessment of British Historians (Calcutta, 1970); Cyril H. Philips (ed.), Historians of India, Pakistan and Ceylon (London, 1961); Siba Pada Sen (ed.), Historians and Historiography in Modern India (Calcutta, 1973).

5 The most dominant are encapsulated by the paradigms of 'decline' and of its corollary 'the transition to colonialism'. On their nineteenth-century historiographical roots and enduring influence, see Christopher A. Bayly, 'Religion, liberalism and empires: British historians and their Indian critics in the nineteenth century' and Baki Tezcan, 'The New Order and the fate of the old-the historiographical construction of an Ottoman Ancien Régime in the nineteenth century', in Peter F. Bang and Christopher A. Bayly (eds), Tributary Empires in Global History (Houndmills, 2011), pp. 21-47, 74-95.

6 Ewout Frankema, Gagan D. S. Sood and Heidi Tworek, 'Editors' note-global history after the Great Divergence', Journal of Global History 16:1 (2021), p. 2. This note argues that overcoming unwarranted ethnocentrisms, anachronisms, essentializations, and path dependencies is a primary motivation in today's global history. It goes on to flag several promising approaches elaborated in the field. Also of relevance is the recent plea for historical scholarship unshackled from 'cognitive eurocentrism' in Richard Drayton and David Motadel, 'Discussion: The futures of global history', Journal of Global History 13:1 (2018), pp. 1-21. 
historiography between the sixteenth and nineteenth centuries, and on the cognitive framework within which Mughal officials operated in around 1700.

The foregoing analysis is facilitated by an approach that stands apart from those normally adopted by others who have worked on the subject. Scholars to date have tended to analyse texts with historical content, be it within the same genre or across genres, by focusing on either their philological or, more recently, their discursive dimensions. ${ }^{7}$ My approach, in contrast, draws upon the traditions of historical sociology and conceptual history to focus instead on their material and cognitive dimensions. ${ }^{8}$ At the core of this approach lies a heuristic model that enables constants and contingencies to be distinguished in a systematic manner. The constants are the near-universal conditions and problems characteristic of known complex polities. ${ }^{9}$ The contingencies are the structures and solutions embedded in specific contexts. In this model, attention is directed, on the one hand, to the structures out of which the historically consequential conditions were fashioned and, on the other, the solutions which addressed the historically consequential problems. ${ }^{10}$ Deploying this model to analyse the Mughal histories composed around 1700 gives rise to the detailed findings in the article's central sections. These findings in aggregate provide us with a purchase on how Mughal elites of the time conceptualized and related to their empire as a functioning entity. More specifically, they elucidate the political sociology that contemporary high officials held in common. Some aspects of this political sociology clash with the views pervading the modern scholarly mainstream; others complement them.

A large number of works with historical content were written by and for the Mughal elites, many of which survive in multiple copies. In volume, sources,

7 For example, Peter Hardy, Historians of Medieval India: Studies in Indo-Muslim Historical Writing (London, 1960); Khaliq Ahmad Nizami, On History and Historians of Medieval India (New Delhi, 1983); Ali Anooshahr, 'Mughal historians and the memory of the Islamic conquest of India', Indian Economic and Social History Review 43:3 (2006), pp. 275-300; A. Azfar Moin, 'Messianism, heresy, and historical narrative in Mughal India', in Orkhan Mir-Kasimov (ed.), Unity in Diversity: Mysticism, Messianism and the Construction of Religious Authority in Islam (Leiden, 2013), pp. 393-413.

8 Signal works in historical sociology that shaped this article's approach include: Shmuel N. Eisenstadt, The Political Systems of Empires (New York, 1963); Samuel E. Finer, The History of Government from the Earliest Times, 3 vols (Oxford, 1997); Ernest Gellner, Plough, Sword and Book: the Structure of Human History (Chicago, 1988); Michael Mann, Sources of Social Power, 4 vols (Cambridge, 1986-2013). On conceptual history (Begriffsgeschichte), see the essays by Reinhart Koselleck, The Practice of Conceptual History: Timing History, Spacing Concepts (Stanford, CA, 2002) and in his Futures Past.

9 Complex polities, including those of the Mughals, were all citied, literate, and commercialized. Such polities were framed by the near-universal conditions of centripetal institutions, a sovereign ideology, indirect rule, and plural populations. The near-universal problems that they faced turned on loyalty, intelligence, chains-of-command, succession, revenue, rights, justice, dispute resolution, resource distribution, public works, population size, social welfare, reputation, security, livelihood, strangers, aliens, memory, and unity.

10 For more information on this heuristic model and the approach within which it is embedded, see Gagan D. S. Sood, 'Knowledge of the art of governance: The Mughal and Ottoman empires in the early seventeenth century', Journal of the Royal Asiatic Society 30:2 (2020), pp. 259-264. 
content, range, style, and authorship, they mark a significant advance on what had previously been seen in the Indo-Persian or Persianate world. ${ }^{11}$ For the purposes of this article, the works of interest are those composed around 1700 , during the high-water mark of the empire's territorial reach, which minimally cover most of the Mughal past down to their date of completion. Only four meet these requirements: ${ }^{12}$ Mir'ät-i jahān-numā by Muhammad Baqā̄ (1627-1683), Lubb al-tawārikh by Vindrāvandās (d. after 1690), Khulāṣat al-tawārīkh by Sujān Rāi (d. after 1696), and Muntakhab al-tawārïkh by Jagjīiandās (d. after 1709). The historical portions of these works, none of which were officially commissioned or sponsored, are structured by dynasty and reign, and stress political, military, and administrative affairs, as is typical of their genres. More specifically:

I. Mir'āt-i jahān-numā (hereafter, 'Mj') is a general compendium of world history, with a substantial biographical section, whose account of the Mughal past goes up to the tenth year of Aurangzeb's reign (1668). The reigns of Babur, Humayun, and Akbar are presented as a series of selfcontained topics, while the remainder takes the form of a yearly chronicle. Its author, Muhammad Baqāa, ${ }^{13}$ occupied the positions of bakhshī (paymaster) and vāqi'a-nigār (daily chronicler) at Aurangzeb's court. Left unfinished at his death, the work survives in two recensions completed posthumously, one in 1684 by his nephew and the other in 1699 by his brother. ${ }^{14}$

11 Indo-Persian historiography, including the exceptional contributions made by the Mughals, is surveyed in Asim Roy, 'Indo-Persian historical thoughts and writings', in José Rabasa et al. (eds), The Oxford History of Historical Writing, Vol. 3, 1400-1800 (Oxford, 2012), pp. 148-172; Blain Auer, 'Persian historiography in India', in John R. Perry (ed.), Persian Literature from Outside Iran: The Indian Subcontinent, Anatolia, Central Asia, and in Judeo-Persian (London, 2018), pp. 94-139.

12 These are four of several hundred works with historical content composed in the latter seventeenth and early eighteenth centuries. For useful guides to this corpus, see 'Abd al-Latîf Ṭālibī, 'Tārīkh-nigārī-i Fārsī aur 'ahd-i 'Ālamgīì' [in Urdu], in Shāh Muhammad Wasīm (ed.), Hindūstān mein

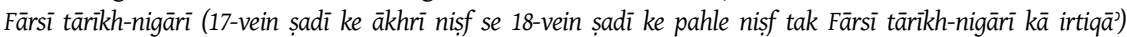
(New Delhi, 2003), pp. 7-15; Nabi Hadi, 'Major historians of later half of the 17th to early half of 18th century A. D.', in Shah Muhammad Waseem (ed.), Development of Persian Historiography in India: From the Second Half of the 17th Century to the First Half of the 18th Century (New Delhi, 2003), pp. 92-98.

13 On Muhammad Baqā̄, see Henry M. Elliot and John Dowson, The History of India, as Told by Its Own Historians: The Muhammadan Period (London, 1877), pp. vii, 153-155; M. Hidayet Hosain, 'Muhammad Bakâà', in Charles E. Bosworth et al. (eds), The Encyclopaedia of Islam (2nd edn, Leiden, 1993), pp. vii, 432-433. There is a debate over the authorship of Mirāat-i jahān-numā, which some attribute instead to Muhammad Baqā̄'s friend and Aurangzeb's secretary and confidant, Bakhtāvar Khān. For the pros and cons of this, see Elliot and Dowson, The History of India, pp. vii, 150-153; Maulavī Șadīq Husain, 'Mir'āt al-ālam-Mir'āt-i jahān-numāa' [in Urdu], Oritantal kālij maigazin 5:1 (1928), pp. 8-22; 'Alā' al-Dīn Khān, 'Bakhtāvar Khān kī tașnīf Mir'āt al-'ālam kā ta'āruf [in Urdu], in Wasīm (ed.), Hindūstān mein Fārsī tārìkh-nigārī, pp. 70-88; Vikas Rathee, 'Bakhtāvar Khān', Encyclopaedia of Islam, THREE (2015).

14 These recensions have not been published or translated. Details on surviving manuscript copies of Mir'ät-i jahān-numā' are given in Charles A. Storey, Persian Literature: A Bio-Bibliographical Survey (London, 1970 [1927-1939]), pp. i, 133-134. The copy examined for this article is held in the British 
II. Lubb al-tawārikh (hereafter, 'Lt') is a general history of India through to 1689-90. Narrated as a series of loosely tied topics, its author, Vindrāvandās, ${ }^{15}$ who occupied the position of dìvān (high-level revenue or finance official), completed the work in 1694-95. ${ }^{16}$

III. Khulāșat al-tawārikh (hereafter, 'Kt') is a well-known general history of India from the earliest times to the conflict surrounding Aurangzeb's succession in the late 1650s, and includes a geographical description of India. The historical portion is narrated as an integrated series of distinct episodes. Its author, Sujān Rāi Bhandārī ${ }^{17}$ was a munshī (secretary) in the employment of high officials, and completed the work in $1695-96 .^{18}$

IV. Muntakhab al-tawārikh (hereafter, 'Mt') is a short general history of India up to the immediate aftermath of Bahādur Shāh's accession in 1707, and incorporates a statistical account of the empire ordered by Bahādur Shāh. Drawing heavily on Lubb al-tawārikh for the earlier sections, it is narrated as a series of loosely tied topics. The author, Jagjīvāndās, ${ }^{19}$ was a harkārah (official concerned with intelligence and communication) and completed the work in $1708-09 .^{20}$

There exist important differences between these four histories. Several are a direct function of their overall length, which varies considerably and is

Library under the class mark I.O. Islamic 1497. It is 519 folios in length, with the Mughal past covered on ff. $315 \mathrm{v}-381 \mathrm{v}$.

15 On Vindrāvandās, see Elliot and Dowson, The History of India, pp. vii, 168-169; Storey, Persian Literature, pp. i, 452-453.

16 Lubb al-tawārikh has not been published or translated. Details on surviving manuscript copies are given in Storey, Persian Literature, pp. i, 453. The copy examined for this article is held in the British Library under the class mark Add. 26251. It is 210 folios in length, with the Mughal past covered on ff. $64 \mathrm{r}-131 \mathrm{r}$.

17 On Sujān Rāi, see Henry Beveridge, 'The Khaláșat-al-Tawáríkh, or Essence of History ...', Journal of the Royal Asiatic Society 26:4 (1894), pp. 733-738; Mohammed Shafi, 'Sudjān Rāy Bhandārī', in Bosworth et al. (eds), The Encyclopaedia of Islam, pp. ix, 762-763; 'Alīm Ashraf Khān, 'Hindūstānī Fārsī tārīkh-nigārī mein munshī Sujān Rāi Bațālvī kā hișșa Khulāșat al-tawārīkh ke havāle se' [in Urdu], in Wasīm (ed.), Hindūstān mein Fārsī tārïkh-nigārī, pp. 51-54; Muhammad Irshād 'Ālam, 'Tașhịh va tadvinn-i Khulāṣat al-tawārỉkh', PhD thesis, Aligarh Muslim University, 2013, pp. 30-34.

18 Khulāsat al-tawārikh exists in several editions. Its geographical sections (though not the historical) have been translated. Details on surviving manuscript copies, published editions, and translations are given in Storey, Persian Literature, pp. i, 455-458. The copy examined for this article is the unpublished critical edition by 'Ālam, 'Tașhịh va tadvīn-i Khulāșat al-tawärikh'. It is 696 pages in length, with the Mughal past covered on pp. 417-745. Unfortunately, the edition contains many mistakes. To correct them, it has been examined in concert with the earlier published edition by M. Zafar Hasan, The Khulasatu-t-Tawarikh (Delhi, 1918).

19 On Jagjīvāndās, see Storey, Persian Literature, pp. i, 458.

20 Muntakhab al-tawārikh has not been published or translated. Details on surviving manuscript copies are given in Storey, Persian Literature, pp. i, 458-459. The copy examined for this article is held in the British Library under the class mark Add. 26253. It is 100 folios in length, with the Mughal past covered on ff. 20r-51r. 
reflected in the number of individuals, events, and themes covered, as well as the amount of detail provided. Other differences, however, seem to result from the predispositions or ideological bearing of the authors themselves. On the face of it, these latter are related to their degree of attachment to Islamic orthodoxy or, alternatively, their openness to religious (and ethnic) plurality. Perhaps unsurprisingly, as the sole Muslim author among the four, Muhammad Baqā's attitudes tend most towards Islamic orthodoxy. This may be seen in his condemnation of Akbar's purported heresy (and concomitant reluctance to condemn Bairām Khān's monopolization of power while regent during Akbar's minority), his disparagement of Hemu (the low-born Hindu official who went on to become a ruler during the Suri interregnum), and his evident sympathy for Aurangzeb's Sunni character and policies. Of all the authors, Sujān Rāi, a Khatri Hindu, is most explicit about the realities of plurality and partial to its virtues. To wit, he studiously avoids criticism of Sher Shah (who drove the Mughals out of Hindustan), of the Rajputs (even when acting in opposition to the reigning padshah), and of Dārā Shikoh (Aurangzeb's heterodox rival for the throne). These differences notwithstanding, Islam or Hindu-Muslim distinctions are not fundamental to the interpretations of the Mughal past found in the four histories. Furthermore, the differences which do exist pale before the similarities between them. It is the very pervasiveness of these similarities that underpins the reasoning of the sections below. The working rule-of-thumb in those sections is that, unless shown to the contrary (every substantial instance of which is noted in the text), the basic attitudes expressed by one author are presumed to have been shared with the others. By extension, given the wide spectrum of careers, traditions, and communities embodied by the four authors, it is reasonable to take their shared attitudes as commonplace within Mughal officialdom of their time.

Adopting the approach outlined above, the histories have been analysed in order to recover what were considered to be the most acute problems faced by ruling elites in governing the Mughal empire and the manner in which they were addressed in the past. Centre-stage is given to the specific solutions proposed, attempted, or enacted to the problems regarded as especially pressing or significant in defined contexts. The histories make clear that the authors were primarily concerned with loyalty and unity-and their counterparts, disloyalty and disunity. ${ }^{21}$ These concerns lay at the heart of a political sociology of empire. Loyalty in their conception depended on ensuring the acquiescence of elites, officials, and intermediaries to the prevailing dispensation for the continuance of the regime. This highlights the constitution of the body politic and the ideology imbuing it. Unity, on the other hand, pivoted on the capacity of the larger polity to withstand or organically adapt to structural changes or unexpected shocks. This highlights the unifying commonalities within its boundaries, not least confessional and linguistic, and to the forces, often

21 There is some discussion in the histories of the problems of revenue, chains of command, intelligence, and succession, but it is minimal in comparison to the space devoted to the problems of loyalty and unity. 
coercive, that pre-empted or defended against fragmentation. In what follows, a section is devoted to each of these in turn, before concluding with a discussion of how contemporary officials understood the developing nature of their empire down to the end of the seventeenth century.

\section{Elite loyalty}

Running through all four histories is a concern with the ways in which elite loyalty to the Mughal regime (saltanat) was secured-or not, as the case may be. The elites in question were the key makers of decisions regarding sovereign governance, and embraced rulers, courtiers, ministers, administrators, and intermediaries. As much attention is paid by the authors to the perceived successes as to the perceived failures in securing elite loyalty. Core to their articulation of these is a calibrated system of generalized exchange. That system buttressed a moral economy within which the careers of Mughal elites were rationalized. ${ }^{22}$

The depiction of this moral economy has elements familiar to modern scholarship. ${ }^{23}$ It was marked by a hierarchy of grades or degrees (manzilat, martabat, darajah), famously institutionalized by the Mughals in the form of enumerated ranks (mansab). ${ }^{24}$ The existence of these ranks is first noted in the histories, albeit fleetingly, early in Akbar's reign. ${ }^{25}$ As the authors describe it, the underlying system had two mutually generative and reinforcing dimensions, one symbolic, the other material. These dimensions corresponded to each other in an inverted fashion. Inferiors ritualistically humbled themselves before superiors, paying homage or making obeisance in keeping with prevailing norms $(\bar{a} d \bar{a} b)$. That went hand-in-hand with inferiors receiving income defined by a numerical zāt which equated to either a cash salary from the treasury or revenue allocated from demarcated territories, and was augmented by awards of money, coined precious metals, or tax exemptions. This exchange was paralleled by another exchange, in which superiors honoured inferiors with titles (khitāab) and other conspicuous marks of favour, such as personal robes of honour (khil'at-i khāsșah), jewelled daggers, horses with gilded saddle and harness, or jewelled pen cases. In return, inferiors typically gave superiors

22 Applying the notion of a moral economy to the ruling elites, as is done in this article, parts company with normal usage, which tends to associate it with non-state actors. That was certainly true of the early, seminal contributions, above all by Edward P. Thompson, 'The moral economy of the English crowd in the eighteenth century', Past and Present 50 (1971), pp. 76-136 and James C. Scott, Moral Economy of the Peasant (New Haven, CT, 1976). For a good critical review of the scholarly literature, see James G. Carrier, 'Moral economy: What's in a name', Anthropological Theory 18:1 (2018), pp. 18-35. On generalized exchange, see Peter M. Blau, Exchange and Power in Social Life (New York, 1964); Peter Palmer Ekeh, Social Exchange Theory: The Two Traditions (Cambridge, MA, 1974); Shmuel N. Eisenstadt and Luis Roniger, Patrons, Clients and Friends: Interpersonal Relations and the Structure of Trust in Society (Cambridge, 1984).

23 The moral economy depicted in this paragraph is a composite which draws upon, and harmonizes, with the details contained in the four histories.

24 These ranks were either totally or partially ordered. On these notions, see H. F. Mattson, Jr., Discrete Mathematics with Applications (New York, 1993).

$25 \mathrm{Kt533,} \mathrm{Mj326v.} \mathrm{Greater} \mathrm{detail} \mathrm{in} \mathrm{the} \mathrm{histories} \mathrm{is} \mathrm{reserved} \mathrm{for} \mathrm{later} \mathrm{reigns.}$ 
valuable gifts ( pishkish, nadhar) and their service in a personal or official capacity at court, or in a military capacity in the provinces specified in terms of number of horsemen (savār, dū-asbah, sih-asbah). ${ }^{26}$

A particular interest is shown in the symbolic dimension of these exchanges. Its significance appears to stem from its function in communicating the relative positions of those concerned within their shared moral economy. By the same token, the symbolic choreography of formal interactions among ruling elites was important enough to be a cause of public deliberation, humiliation, and even armed conflict. For a long time, 'in keeping with the practice of South and North India (Daccan va Hind)', 27 it was customary for recipients of a favour or an order from the ruler to prostate themselves before him (sajdah). One of the first decrees issued by Shah Jahan on coming to the throne in 1628 was, so the histories say, to abolish this practice as only proper for god alone. 'Kissing the ground' (zamin-büs) was proposed as an alternative. Its proponents argued that it maintained 'the thread of distinction between servant and master'. ${ }^{28}$ Shah Jahan accepted this, though 'sayyids and scholars and the virtuous and the pious were exempted this practice', from whom a salutation (saläm, taslim) sufficed. ${ }^{29}$ But that did not bring the matter to an end. 'Because zamin-būs is similar to sajdah and sajdah is suited to the court of the creator', ${ }^{30}$ this too was abolished several years later and in its place Shah Jahan 'added one salutation to the normal three salutations'. ${ }^{31}$ Protocol is also central to the account of the disgrace of the Mughal pretender Kāmrān. After being defeated in 1551 by his elder brother in the environs of Kabul, Kāmrān reached out for help to Islām Shāh, the Suri ruler in northern India. Islām Shāh sent a welcoming party headed by his son. On Kāmrān's arrival, 'because of pride or contempt for the prince [Kāmrān], Islām Shāh did not face [him] and he was completely ignored... The prince's honour (ābirū) was violated. In the end, Islām Shāh met the prince with half-hearted respect. This added to the prince's disgrace. ${ }^{32}$

The symbolic dimension is placed at the root of a conflict which, the authors contend, shaped the very origins of the Mughal empire. Ibrahim Lodi, the last of the Delhi sultans, is quoted as having said: 'Padshahs are not comparable with any person. Everyone is [their] servant (naukar). ${ }^{33}$ This view was given force when on Ibrahim's accession in 1517 'he changed the formal manner [of interacting with] his kith and kin (khvish va qaum)' ${ }^{34}$ Those who had sat in the presence of his father and grandfather were now 'forced

26 In the histories, specification of military service in terms of number of horsemen dates from Jahangir's reign: Kt623, Lt83v, Lt94v, Mj332v.

27 Lt79r, Mt27r.

$28 \mathrm{Mj} 338 \mathrm{r}$.

$29 \mathrm{Mj} 338 \mathrm{r}$.

$30 \mathrm{Mt} 27 \mathrm{v}$

31 Lt79r-79v, Mj338r.

$32 \mathrm{Kt} 483$.

33 Lt63v.

34 Lt63v. 
to stand hands folded before the throne'.$^{35}$ All the histories point out that this innovation offended several of his umara $\bar{a}^{36}$ After experiencing further illtreatment, these umara $\bar{a}^{3}$ turned against Ibrahim and eventually went over to Babur's side, helping him to achieve his long-held desire to conquer Hindustan. ${ }^{37}$ Through recounting events like this, the authors stress the close relationship between elite loyalty and symbolic expressions of deference and respect in formal settings. These symbolic expressions were evidently vested within a well-defined moral economy. If its parameters were transgressed, loyalty to a superior was undermined, considerably heightening the risk of opposition. Such is the significance accorded it in the histories that, as seen with the Lodis and Mughals, transgressions could hasten the end of one dynasty and the start of another.

Structurally, the ideas and practices which crystallized the moral economy served to incorporate-and, importantly, reincorporate-select individuals, organizations, and groups into the imperial regime's body politic. The authors describe this as usually happening in identifiable physical settings, most commonly the 'court' (dargāh) or 'palace' (daulat-khānah) within a city, fortress, or encampment. Mentioned as well are the physical settings of the more modest 'house' (khānah), 'mansion' (havilì), and 'pavilion' (khaimah). The daily meetings (mahfil) and assemblies (majlis) of the ruling elites were held in these settings. They also hosted festivals ( jashn) and feasts (bazm) to celebrate special occasions, such as the birth of a potential heir, the anniversary of the current ruler's accession or a major victory in a military campaign. It is during these gatherings that the symbolic and material exchanges noted above took place. In tandem, more ad hoc mechanisms were deployed with a bearing on the loyalty of elites. As a display of singular favour, the ruler might seat an official or intimate immediately beside him. ${ }^{38}$ Conversely, he might banish the official or intimate from his presence to demonstrate his manifest displeasure. $^{39}$ These are of a piece with the idea that proximity to a superior mattered, reflected in the authors' fulsome accounts of formal gatherings. ${ }^{40}$

Generalized exchanges were routine in nature. They were modulated by a set of tactics which, according to the histories, were of particular value in incorporating new figures into the Mughal elites and in reincorporating those who had turned against the padshah but remained loyal to the regime. Foremost among these was mediation. We occasionally see leading officials

35 Mt19v-20r.

36 Umara $\bar{a}$ ' is often translated as 'nobles' in modern scholarship. But the word's meanings in the histories cannot be readily mapped onto that. This is why here and elsewhere it is written out in transliteration.

$37 \mathrm{Kt}, \mathrm{Lt}$, and Mt note that Babur succeeded in conquering Hindustan on his fifth attempt, whereas in Mj success occurred on the fourth attempt. In all the histories, Hindustan is the premier arena in which the Mughal past was played out. The area's geography as the authors imagined it is discussed in the next section.

38 For example, Lt75v, Mj331v, Mj332v, Mj346v, Mt36v.

39 For example, Kt502, Lt74v, Mj343v, Mt25r.

40 For example, Kt543-544, Kt564-565, Kt636-637, Kt726-728, Lt78r-78v, Lt105v, Lt114v-115v, Mj365r-365v, Mj368r-368v. 
playing this role, like the Khān Khānān in Akbar's reign. ${ }^{41}$ However, greatest regard as mediatorsis reserved for members of the ruler's immediate family. Adult sons brought rebels who were unrelated to the Mughal dynasty by blood or marriage back into the fold, ${ }^{42}$ while queen mothers managed to bridge differences within the Mughal ruling family, especially between brothers and between fathers and sons. ${ }^{43}$ Mediation coheres with that facet of sovereign loyalty which was highly personal. That facet is also in evidence in the tactic of summoning to court the children of autonomous elites who wielded considerable influence in their homeland. This tactic is mentioned primarily in dealings with vanquished opponents. In Shah Jahan's reign, the sons of the Turani ruler Nadhar Muhammad Khān were ordered to court following his submission, and there they willingly stayed. ${ }^{44}$ After his defeat in 1639, Jujhār Singh Bundela's young children were hauled before Shah Jahan, converted to Islam, and reared by 'trusted people'. ${ }^{45}$ The rationale in both cases is clear: the children were leveraged as guarantors for the continued loyalty of local elites. Moreover, there was an expectation that when grown up they would go on to serve the regime as high officials. This was underpinned by the purposeful intermingling of elite households, and the ties of intimacy thereby fostered. That intermingling is explicit in a third tactic, the use of judicious concubinage and marriages to create affective ties between the lineages of families who furnished the current and future ruling elites of the empire. This is said to have been initiated by Babur, ${ }^{46}$ whose policy his grandson Akbar embraced and elaborated. Leading by example after his accession, Akbar took into his harem the niece of 'one of the main zamindārs of Hind'. Later he married the daughter of Raja Bharamal Kachhwaha, 'the chief raja' of the empire. ${ }^{47}$ 'Despite religious differences, [the rajas and Akbar] considered [themselves] exalted by these ties. From both sides, they opened this way. ${ }^{48}$

These ideas, practices and tactics of incorporation and reincorporation were, the authors suggest, normally enacted in the ruler's court or palace. That suited the metropolitan elites whose service was oriented largely towards the ruler and his regime. This did not hold, however, for other categories of elites, especially autonomous headmen of ethnic communities. These headmen, who often ruled over substantial areas where their kindred resided, were crucial as linchpin figures between the Mughal regime and the general population. The histories give most prominence to Afghans and Rajputs. Bearing Mughal titles, like zamindār and marzbān, or traditional non-Persian titles, like rānā, rāi, and $r \bar{a} j \bar{a}$, the headmen of these communities supplied intermediaries par excellence. Furthermore, by virtue of their Janus-faced character -being rooted in their homelands while simultaneously occupying an official

\footnotetext{
$41 \mathrm{Mj330v.}$

42 For example, Kt563, Kt597, Mj346r-346v.

43 For example, Kt457, Kt618, Mj319r, Mj324r, Mj350v-351r.

44 Lt82r, Mt28r-28v.

45 Lt84r.

$46 \mathrm{Kt} 540$.

$47 \mathrm{Kt} 540$.

$48 \mathrm{Kt} 543$.
} 
position-the manner in which they related to the regime makes them qualitatively distinct from the more deracinated metropolitan elites. Securing their loyalty is thus treated differently by the authors. These headmen seldom appear in the histories, ${ }^{49}$ perhaps because of the rarity with which they came before the ruler and his highest officials. But that did not make them marginal to the concerns of sovereign decision-makers in the heartlands. Intermediaries were recognized as members of the empire's ruling elites. This explains why the padshah intervened personally to determine succession following the death of a Rajput raja, ${ }^{50}$ and elsewhere left a local ruler in no doubt that if he failed to obey the imperial writ he would be replaced by his brother. ${ }^{51}$

Managing popular opinion through public display is a central motif of sovereignty loyalty. The authors are at pains to show that the Mughals were no exception to this. As they interpret it, the main audience was not the general population but the empire's ruling elites. Several of the forms taken by this display had a cosmic quality to them. Both Akbar and Shah Jahan made well publicized, prearranged pilgrimages to the tomb of Khvāja $\mathrm{Mu}^{\mathrm{c} i \mathrm{in}}$ al-Dīn Chistī in Ajmer. ${ }^{52}$ Other pilgrimages occurred en route while on vacation tours or during military campaigns. ${ }^{53}$ Whether the avowed purpose was to request a special favour or give thanks, pilgrimages were among the most visible acts of personal piety by a ruler. Through them, the ruler came to be associated with the mystique and wisdom of figures often venerated for being "connected to the Truth (haqq) and close to the Absolute Living Being (haiy-i mut laq). ${ }^{54}$ Some of the same associations were evoked through the practice of taking auguries and casting horoscopes. ${ }^{55}$ The authors comment on eminent astronomers and astrologers being engaged to tell the fortune of a newborn heir and his future reign, ${ }^{56}$ and to determine the most auspicious hour for embarking on a military conquest ${ }^{57}$ or for ascending the throne for the first time. ${ }^{58}$ This knowledge was then widely disseminated.

Religious and seasonal festivals carried similar force. The histories document a number of traditional festivals, such as 'İd al-Fițr and Nowruz, being observed by Mughal elites, often in a lavish, even spectacular, fashion. ${ }^{59}$ Alongside these, new festivals were inaugurated, like the jashn-i vazn by Akbar, which went on to become established fixtures in the courtly calendar. ${ }^{60}$

49 For an exception, see Mt38v.

50 Lt116v-119v.

$51 \mathrm{Mt} 46 \mathrm{v}$.

52 Kt542, Mj328r, Mj340v-341r, Mj342v-343r.

$53 \mathrm{Kt724,} \mathrm{Kt731.}$

$54 \mathrm{Kt5} 42$.

55 Mughal attitudes to predestination and fate are examined in A. Azfar Moin, The Millennial Sovereign: Sacred Kingship and Sainthood in Islam (New York, 2012).

56 Kt453, Kt636-637.

57 Kt469-470, Kt488.

58 Kt494, Kt622, Lt105r-105v, Lt114v, Mj355v, Mj361r.

59 For example, Kt597-599.

60 For example, Kt538. 
Public display was also used to highlight the Mughal dynasty being in direct descent from Timur. Anniversaries provided opportune moments for reminding subjects of this fact. 'In the second year after the victory at Samugarh, [Aurangzeb] celebrated in the manner of the Lord of the Conjuncture, the custom of Amir Tìmūr. No one had ever celebrated in such a way that the eyes of the high and low glittered with so much splendour. ${ }^{61}$ These remarks indicate the respect, if not awe, in which Timur was held by the time the histories were composed.$^{62}$ That derived in part from his renown as a great conqueror and in part from him being the culmination of a tradition initiated by Genghis Khan. ${ }^{63}$ Cleaving to this genealogy evidently helped sustain the aura surrounding the current padshah and his family.

As the authors articulate it, generosity was integral to many public displays of Mughal sovereignty. This is no truer than during the celebrations surrounding the accession of a new padshah. From the time of Jahangir, the histories luxuriate in the higher ranks, elevated titles, and valuable gifts received by the princes, great nobles, and imperial bondsmen. ${ }^{64}$ The accessions of Babur and Humayun are, in contrast, glossed in a simpler manner, with generosity mainly taking the form of money grants and territorial assignments. ${ }^{65}$ Generosity was part-and-parcel of success on the battlefield, too. All ranks in the victorious army, not just its leaders, are frequently mentioned as sharing in the spoils from the defeated side. The defeated could also be beneficiaries of a ruler's largesse. If the enemy had fought honourably and reconciliation was a possibility, the authors usually portray the Mughals as magnanimous in victory. Both features figure prominently in the founding of the Mughal regime. After seizing the vanquished Ibrahim Lodi's treasury in Delhi, 'ten

$61 \mathrm{Mt30v}$. The original expression dastūr-i Șāhib-Qirānī has been translated somewhat loosely here as 'the manner of the Lord of the Conjuncture, the custom of Amīr Tīmūr' in order to convey its two entwined meanings familiar to Mughals of the time. The narrower invokes Timur, who in the histories is synonymous with Șăhib Qirān. In almost every instance of this term and its cognate, Săhib-Qirānī, the sole or primary reference is either to the man or to the tradition associated with him or to his lineage. The broader meaning is that of the universal sovereignty of an individual undefeated in battle and thus cosmically ordained to conquer the world. This was exemplified by Timur, though the term was also taken as a title by a host of rulers, Timurid and non-Timurid, before and after Timur, and deployed as an attribute of figures of epic lore. On the term's usage within the region at large, see Stephen P. Blake, Time in Early Modern Islam: Calendar, Ceremony, and Chronology in the Safavid, Mughal, and Ottoman Empires (Cambridge, UK, 2013), pp. 165-169, 171-173; Cornell H. Fleischer, 'A Mediterranean apocalypse: Prophecies of empire in the fifteenth and sixteenth centuries', Journal of the Economic and Social History of the Orient 61:1-2 (2018), pp. 18-90.

62 This positive view of Timur appears to date from Shah Jahan's reign. Changing views on Timur and the Mughals' purported Timurid genealogy are discussed in Irfan Habib, 'Timur in the political tradition and historiography of Mughal India', in Maria Szuppe (ed.), L'héritage timouride: Iran, Asie centrale, Inde XVe-XVIIIe siècles (Aix-en-Provence, 1997), pp. 297-314; Ali Anooshahr, 'Mughals, Mongols, and Mongrels: The challenge of aristocracy and the rise of the Mughal state in the Tarikh-i Rashidi', Journal of Early Modern History 18:6 (2014), pp. 562, 571-576.

63 Babur is noted for using in battle military principles (türah, rasam) associated with Genghis Khan, which were likely to have been transmitted by way of Timur. Lt66v, Lt68r, Mt20v.

64 Mt27r, Mt41v, Lt78r, Lt115r-115v, Mj362r, Kt622-623, Kt677, Kt716-717.

65 Kt430, Kt442. 
lakh tangah were awarded [by Babur] to each one of the umarāa, and all of the soldiers, even the men of Babur's army and other people of the umarä' received a reward'. ${ }^{66}$ As for his erstwhile enemy, Babur 'was gracious towards the mother and children and dependents of Sultan Ibrahim. He granted them their personal possessions and treasury. Furthermore, out of compassion eight lakh tangah were arranged for the queen mother as a suyūrghāl. ${ }^{167}$

The effect on those privy to such displays of sovereignty were reinforced by their sensory qualities. For rulers to be seen in a particular way was, the authors suggest, of manifest importance. The histories comment on parasols (chatr) being held above rulers. ${ }^{68}$ When travelling, they did so in style, in palanquins or on elephants. ${ }^{69}$ To be heard in a distinctive fashion was also important. Occasionally, their movement in public is described as accompanied by the playing of drums. It would appear that these sights and sounds immediately and palpably signified the presence of the ruling elites. They were a prerogative of the ruler and of the select few with whom he deigned to share these symbols of sovereignty. By stimulating both eyes and ears, he thereby left a sensory imprint on those in his vicinity. This effect is most intensely registered in and around the courts, palaces, and forts of the regime's major cities. But the histories make clear that it was not confined to them. By virtue of the tours and hunts (sair va shikār) regularly undertaken by the Mughal court, the sights and sounds accompanying it were dispersed more widely within the empire. Akbar's Gujarat campaign of the early 1570 s to defeat the rebellious mirzās, who, like him, were descendants of Timur, combined the conquest of a new vilāyat with a trip to see its land and people, and the Arabian Sea (daryā-yi shür). ${ }^{70}$ In more peaceable times, Jahangir and his entourage visited the same area. They toured Ahmedabad, took in the Arabian Sea, and hunted elephants. ${ }^{71}$ But much more common-and storied-are the trips to Kashmir. After submitting to the Mughal empire in the latter half of Akbar's reign, we learn that the padshahs became habitués of the area, delighting in the area's exquisite gardens, waterways, and flora. ${ }^{72}$

There is no denying that such trips, whether for sightseeing or some other reason, brought the metropolitan Mughal elites to areas of the empire far removed from the traditional heartlands centred on Delhi, Agra, and Lahore. But the prevailing transport and communications technologies, coupled with the natural challenges posed by mountains, deserts, and the rainy season, meant that touring, while noteworthy as an event, was inevitably piecemeal and episodic. It was not-and could not have been-critical to sovereign governance in the Mughal empire at large. In terms of reach and circulation, much more effective in disseminating awareness of the padshah's authority,

66 Kt430; also Lt69r, Mt21r, Mj317r.

67 Kt430; also Lt68v.

68 For example, Lt98v, Mt22v.

69 For example, Kt725, Kt726, Lt98v, Mj364v, Mt29v.

$70 \mathrm{Kt} 521-523$.

71 Kt634, Mj332v-333r.

72 In Abkar's reign: Kt578, Kt579-582, Kt586-588, Kt588; in Jahangir's reign: Kt653-655, Mj333r333v; in Aurangzeb's reign: Mj369v-370r. 
especially among the ruling elites, were eulogies written by celebrated poets, such as by the 'king of poets' (malik al-shu'arā') Abu al-Faid Faidīi ${ }^{73}$ and fatah-nāmahs publicizing major victories by Mughal armies. ${ }^{74}$

Much of the authors' focus is either on the ruler and his environs, or on the heartlands of the Mughal empire. Though these did not always physically coincide, both were characterized by the conspicuous presence of the metropolitan ruling elites. Reflecting their prominence is the interest in the signal policies marking a given ruler's approach to government, variously termed saltanat, jahāndārī, and jahānbāni. After the fall of the Lodi dynasty, according to the histories, the main task faced by Babur was securing the loyalty of the local elites (acyann) of his newly conquered territories in northern India. ${ }^{75}$ We read that he instituted a novel policy well suited to the area's plural character. This was apparently of interest to the Safavid Shah Tahmāsp, who described the policy as follows: 'After Babur had seized the Khiläfat-i Hind from the control of the Afghans, in that foreign country (mulk-i bigānah) he intermingled with the principal zamindārs. In [this] time of discord, they became [his] helpers and supporters, and in this manner disorder did not happen in the regime. ${ }^{76}$ Echoing Babur, his father, once Humayun had recovered the throne he 'distributed sovereign territories to the jāgirs of the umarāa, ${ }^{77}$ But what really stood him out as a ruler was being 'the creator of the regulations governing most of the grades (marātib)' in the elite hierarchy. ${ }^{78}$

The histories openly acknowledge the debt that later Mughals owed Sher Shah and the Suri interregnum for the effective running of their imperial machinery. ${ }^{79}$ Suri policies were adopted and extended in Akbar's reign. In this, however, the padshah himself is depicted as playing a passive role. ${ }^{80}$ Star billing is given instead to his two leading officials. One was Abū al-Faḍl. 'The affairs of the empire were managed with his counsel', ${ }^{81}$ with special praise reserved for his 'handbook (dastūr al-'amal) on matters of saltanat and jahānbāni, and register of sovereign affairs' ${ }^{82}$ The other official was Todarmal. His enduring fame stemmed from the rules and regulations in the empire' established during his tenure as minister. ${ }^{83}$ These were 'so sound that, although [subsequently] great ministers and great treasurers

\footnotetext{
73 Kt600-601.
}

74 Kt519, Mj325v, Mj326r, Mj344r.

$75 \mathrm{Mj} 317 \mathrm{r}$.

$76 \mathrm{Kt5} 40$.

$77 \mathrm{Mj} 326 \mathrm{r}$.

$78 \mathrm{Lt69v}, \mathrm{Mt} 12 \mathrm{v}$. This apparent innovation is discussed in Shireen Moosvi, 'The evolution of the manșab system under Akbar until 1596-7', Journal of the Royal Asiatic Society 113:2 (1981), p. 174 and Iqtidar Alam Khan, 'State in Mughal India: Re-examining the myths of a countervision', Social Scientist 29:1-2 (2001), pp. 33-34.

79 Kt484, Mj322r.

80 Akbar being given this passive role directly counters his depiction in Abū al-Faḍl's Akbar-nāmah, in which all the cardinal achievements of the reign are credited to Akbar.

81 Kt615-616.

$82 \mathrm{Kt} 493$.

$83 \mathrm{Kt584.}$ 
tried, and continue to try, to destroy those regulations and to invent new laws, they have not and will not manage to do so, ${ }^{84}$

It would seem that in the domain of government administration there was little left for Jahangir to do. 'The formula from Akbar's time for administering revenue prevailed in full and revenue officials also maintained the old system. ${ }^{, 85}$ The authors locate Jahangir's signature policy elsewhere, in the domain of justice. On coming to the throne, he "promised the people to administer justice and do good'. ${ }^{86}$ Evidence shows him endeavouring to keep that promise. ${ }^{87}$ Such was the empire's vaunted prosperity and tranquillity that Shah Jahan was apparently free of any serious pressure to innovate during his reign. He is noted instead for improving the efficacy of inherited policies. This greatly increased the regime's income to more than cover its much higher expenses, while broadening the provision of justice for its subjects. ${ }^{88}$ The authors deem that Aurangzeb's main contribution to routine governance was in relation to the revenue system. He sought to ease the life of his subjects by reducing claims on the imperial treasury from officials and by creating new sources of revenue through, for example, tolls and customs which had hitherto entered the privy purse. ${ }^{89}$ This fiscal initiative is overshadowed, however, by Aurangzeb's purported interest in 'the divisions of the communities of mankind'. ${ }^{90}$ That interest is reflected in his support for policies that discouraged 'innovators and apostates and deviants and atheists and polytheists', and encouraged orthodoxy, particularly in the form of Islam's din and the religious sciences. ${ }^{91}$

How regnal policies were apprehended by the authors echoes their perspective on the Mughal past more generally. The past that mattered most to them was anchored in the great cities of northern India. The epithets normally given to these cities in the histories flag their centrality to the empire. Over the period covered, several were recognized as its contemporaneous metropolitan capitals ( $p \bar{a} i$-takht, pādshāh-nishīn). The apex was invariably occupied by what the authors term Dār al-khiläfah ('Abode of the Caliphate'). Except for a time when Akbar's Fatehpur Sikri took its place, ${ }^{92}$ this term was almost always reserved for Agra. That changes in the middle of the seventeenth century when the recently constructed Shahjahanabad become the premier imperial capital. $^{93}$ Thereafter, Agra is more commonly given the epithet Mastaqarr al-khiläfah ('Seat of the Caliphate') in keeping with its now secondary status. ${ }^{94}$ Through to the end of the histories, Mughal Lahore is frequently denoted by

\footnotetext{
84 Kt585.

85 Lt76v, Mj330r.

$86 \mathrm{Mj} 329 \mathrm{v}$; also Lt76v.

87 Lt77r, Mj330r.

88 Lt79v-80r, Mt27v-28r; also Kt677-678.

89 Mj363v, Mj378v-379r.

90 Mj361r.

91 Mj361r; also Mj362v, Mj378v.

92 Kt541, Kt542, Kt549.

93 Kt678 ff, Lt106r ff, Mj344v ff.

94 Kt684 ff, Lt101r ff, Mj346r ff, Mt30r ff.
} 
Dār al-saltanah ('Abode of the Regime'). This is a testament to the city's importance in the empire's formation and its strategic value geographically. The manner of referring to other cities suggests a more local or particular significance. Those like Kabul and pre-Shajahanabad Delhi, which were primarily known for their political and administrative functions as capitals of the empire's vilayyats, are often designated häkim-nishin ('seat of the governor') and termed Dār al-mulk ('Abode of Dominion'). ${ }^{95}$ Those known for some additional noteworthy quality are given distinctive epithets expressing that quality. So, the authors call Ajmer Dār al-khair ('Abode of Blessing') in reference to its spiritual associations $^{96}$ and, following their conquest by the Mughals in Aurangzeb's reign, Bijapur is denoted Dār al-zafar ('Abode of Victory') and Hyderabad Dār al-jihād ('Abode of Jihad'). ${ }^{97}$

Cities were the sites where two particular aspects of the Mughal past are seen with especial clarity. One is control over, and security of, the ruler's immediate family and close intimates. The sensitivities surrounding them are exemplified by the fate of Akbar as a young child, played out in the 1540s between Qandahar and Kabul. ${ }^{98}$ The second aspect was the machinations of the regime's leading figures with direct access to the padshah. They formed cliques (ta'așsub-i mazhab) around a mix of potential successors, influential officials, and powerful intimates. Though several factional conflicts are detailed, ${ }^{99}$ by far the most intriguing in the eyes of the authors had Nūr Jahān at its heart. After Jahangir married Nūr Jahān, her father and elder brother came to the fore with elevated titles and offices. ${ }^{100}$ In time, 'all [their] intimates and dependents were allocated ranks and distinguished statuses. Even slaves and eunuchs were honoured with noble (khāni and tarkhānī) titles [and] exalted among the elites. ${ }^{101}$ This group is portrayed as engrossing the levers of power in the capital as Jahangir withdrew from affairs of state. That eventually brought Nūr Jahān and her supporters into open conflict with other cliques, led by those centred on Shah Jahan and Mahābat Khān, who ultimately combined forces against her. ${ }^{102}$

The forgoing presents the authors' understanding of how elite loyalty to the regime was addressed by the Mughals. Their working solutions had strengths and weaknesses. Two sets of circumstances recounted in the histories throw both of these into sharp relief. In one set, de jure rulers were incapacitated. This brought to light members of the metropolitan elites responsible for decision-making who would otherwise have remained veiled. According to the histories, incapacitation typically happened in a small number of scenarios. If the ruler was a young child on ascending the throne, and managed to survive the plots against him, the reins of sovereign governance were usually in the

95 For example, Kt498, Kt666, Lt86v, Mj316v, Mj345v.

96 For example, Mj328r, Mj331v, Mj346r.

97 For example, Mt35v, Mt37r.

98 Kt453, Kt457-459, Kt463-464, Lt70v, Lt71v-72r, Mj321r-321v, Mj323v-324v, Mt22v-24r.

99 For example, Kt532, Kt611-618.

100 Mj331r.

$101 \mathrm{Kt} 633$.

102 Kt656-669, Mj334r-337v. 
hands of a recognized regent or council of regents ( pishkārī). That was the situation during the minority of Akbar, the sole instance of a Mughal padshah being too young to rule in person from the start of his reign. When Humayun died, Akbar's guardian (atālīq, tālīq), Bairām Khān, ensured his charge's succession. ${ }^{103}$ Simultaneously, Bairām Khān took over 'all the important sovereign matters' ${ }^{104}$ as 'Khān Khānān of the madār al-mulk and vakil-i saltanat'. ${ }^{105}$ There is a degree of equivocation in the authors' judgement on his regency. Bairām Khān is said to have 'ill-treated the padshah's bondsmen', ${ }^{106}$ and 'by oppressive means many ranks and bountiful jāgirs were permitted for his attendants'. ${ }^{107}$ Nevertheless, 'in his devotion [to Akbar] there wasn't any shortcoming or weakness'. ${ }^{108}$

In another scenario, previously active rulers voluntarily withdrew from the business of government in favour of pleasures of one sort or another. The Mughals down to 1700 experienced this merely once. That one occasion, however, left a deep imprint on how their past was remembered and interpreted. Until the middle of Jahangir's reign, 'the work of saltanat was fully undertaken by him ... [and his] orders fully obeyed'. ${ }^{109}$ But his wine drinking and opium use grew to such proportions that he eventually gave the totality of the matters of governance to the control of [Nūr Jahān] and for himself did not hold on to kingship except the name'. ${ }^{110}$ Nür Jahān is extolled in the histories for her beauty. An author also praises her for her impressive knowledge of, and talent for, dealing with 'the affairs of the regime' ${ }^{111}$ However, that does not seem to have been enough. The consensus view is that her period of de facto rule ended with the imperial polity in a parlous state. ${ }^{112}$

Illness precipitated yet another scenario leading to the ruler's temporary or permanent incapacitation. If this was sudden and unexpected, the histories maintain that instability generally ensued. Of the several instances described, ${ }^{113}$ by far the most consequential was Shah Jahan's illness in the late 1650s. This illness was so severe that he was no longer able to rule and 'disorder entered the management of government business'. ${ }^{114}$ The authors agree that Dārā Shikoh, who alone among Shah Jahan's adult sons was with him in Delhi at the time, became the effective ruler. ${ }^{115}$ They differ, however, over Dārā's suitability for this position. On one side are those pointing out

\footnotetext{
103 Lt72v, Lt73r, Mt24v.

104 Kt500; also Kt494.

$105 \mathrm{Kt} 494$.

$106 \mathrm{Kt} 500$

107 Kt500; also Lt74v.

$108 \mathrm{Lt} 74 \mathrm{v}$.

$109 \mathrm{Mt} 26 \mathrm{r}$.

110 Lt77r.

111 Kt632.

112 Kt657, Kt671, Lt77v, Lt78v, Mt26v-27r.

113 For example, Kt582-583.

114 Kt679; also Lt96v.

115 Kt679, Kt680, Lt96v, Mj347v.
} 
that Shah Jahan 'favoured' Dārāa ${ }^{-116}$ and, even before his incapacitation, was running the empire with Dārā as his 'crown prince (vali-'ahd) and deputy (näib-manāb-i saltanat)'. ${ }^{117}$ On the other side are those who suggest that, when Shah Jahan fell ill, Dārā, because of his 'raw desire to rule', ${ }^{118}$ 'designated himself the crown prince [and] seized the chance to take into his possession the reins of control of the saltanat'. ${ }^{119}$ 'In every matter he acted according to his whims with weak-minded judgement. ${ }^{120}$ There followed an intense, drawnout conflict involving all of Shah Jahan's principal sons. For much of it, Shah Jahan remained the titular padshah, even after Aurangzeb's dominance was no longer in doubt. It was only when Aurangzeb finally accepted that Shah Jahan would always prefer Dārā to him that 'he retired Shah Jahan [and] ascended the throne himself. ${ }^{121}$ The incapacitation of a ruler, in this and other scenarios, gave the authors an opportunity to reiterate a basic truth: the padshah did not monopolize the loyalty of Mughal elites. Rather, it was oriented to something much larger than him, vested partly in a shared ideology and partly in the empire's centripetal institutions.

Dissenters, rebels, and rivals occupy the largest portion of the histories. This coheres with the notion that they were endemic to the empire. The tensions and crises to which these opponents contributed furnish the second set of circumstances, throwing into sharp relief the strengths and weaknesses of how the Mughals addressed the loyalty problem. Like Aurangzeb during the conflict over succession, the dissenters, rebels, and rivals who fall within the scope of this problem continued to obey the same core principles as the incumbent ruler and his supporters. In that sense, they always remained members of the empire's ruling elites even as they defied, constrained, or even threatened the position of the ruler. So, their opposition was qualified, and reconciliation (istimālat) a conceivable prospect. In one group cluster individuals of sufficient gravitas that their dissent could destabilize the empire from the centre. As narrated, the mainstream elites tried to neuter the threats posed by such individuals by, for example, sending them into exile or appointing them to a challenging post far away from the Mughal heartlands. This is typified by the fate of Bairām Khān. While regent in the late 1550s, Bairām Khān's 'power and status became supreme. He exceeded the status of the vakālat and the amir al-umarā', and had total control over all the [imperial] workshops and all [government] business. ${ }^{122}$ When Akbar abruptly dismissed him as regent and from his other posts in 1560 and forbade him from court, 'Bairām Khān did not accept the imperial admonishment'. ${ }^{123}$ He left for Panjab 'with depraved intentions', ${ }^{124}$ seeking

\footnotetext{
116 Kt681.

117 Kt678.

118 Mj348r.

119 Lt96v.

120 Lt96v.

121 Kt681; also Kt698, Lt105r, Mt30r.

122 Kt500.

$123 \mathrm{Kt502.}$

$124 \mathrm{Mt} 25 \mathrm{r}$.
} 
to gain the support of local elites for an uprising against Akbar. ${ }^{125}$ Pursued by Akbar's forces, Bairām Khān was confronted and eventually defeated. ${ }^{126}$ 'In view of his good service', Akbar offered him 'forgiveness and safety'. ${ }^{127}$ Bairām Khān accepted this, came before Akbar, and wept in public. Akbar embraced him, honoured him with a personal robe of honour, seated him as before their breach, fed him from the padshah's plate, awarded him large sums of money, granted parganahs to his dependents, and gave him leave to go on pilgrimage to the Hijāz. ${ }^{128}$

Alongside dissidents, there were rebels who tried to break with the empire and carve out independent regimes of their own in territories over which the imperial writ had hitherto run. The authors give numerous accounts of such attempts. Their instigators represented the whole gamut of the ruling elites. They ranged from the brothers, uncles, and sons of the reigning padshah to zamindārs, vāliss, and hākims in distant territories by way of high-ranking metropolitan courtiers and officials. The exemplary case, described in all four histories, is that of Humayun's brothers. They had been assigned extensive territories of the empire as $i q t \bar{a}^{c}$. But this failed to suffice; they harboured ambitions of ruling a saltanat of their own, a cause of endless trouble for Humayun. The shattering blow came during the conflict with Sher Shah. Not only did his brothers fail to come to Humayun's aid, they actively conspired against him in the hope of becoming independent rulers. In the short term, this hope was realized and new, smaller regimes emerged in areas that had previously been claimed by Humayun as padshah. ${ }^{129}$ In the longer term, however, Humayun's brothers were overcome. On this, like every other occasion of a rebellion or dissidence, their leaders were eventually tamed-by being reconciled with, and reincorporated into, the empire-or eliminated-by being killed in battle, executed, imprisoned, exiled, or forced to flee abroad. That taming or elimination buttresses a grand narrative of ongoing territorial conquest and secular expansion through to the end of the seventeenth century. The Mughals enjoyed unprecedented success on this front, to the extent that the [other] great padshahs do not have a tenth of the extent of the mamlakat of [Aurangzeb].'. ${ }^{130}$

Distinct from dissidents and rebels are those who did not just oppose the sitting padshah but also had a credible claim on the Mughal throne. Without exception, these rivals were in the same line of descent as the incumbent ruler, and feature in most of the reigns covered by the histories. As noted above, Humayun's reign was plagued by opposition from his brothers, the sons of Babur. The authors depict them as resolutely driven by a desire to establish their own regimes separate from the Mughal empire (though an

125 Kt502, Lt75r, Mj327r, Mt25.

126 Kt502-503, Lt75r, Mt25r-25v.

127 Lt75v.

128 Lt75v, Mt25v; also Mj327r-327v. Several details of the account of their meeting differ in Kt503.

129 Kt444, Kt445, Kt448, Kt450-451, Kt453-454, Lt69v-70r, Mj319r-321v, Mj322r-322v, Mt21v22 r.

$130 \mathrm{Lt} 4 \mathrm{v}$. 
instance is recounted of an attempt by Hindal to dethrone Humayun and take his place). ${ }^{131}$ Jahangir faced a threat from his son Khusrau early in his reign which he ruthlessly suppressed. ${ }^{132}$ After his withdrawal from affairs of state, the remainder of Jahangir's reign is characterized as riven by a struggle for power between the camp supporting Shahryār's claim and the camp supporting Shah Jahan's claim. ${ }^{133}$ Shah Jahan, of course, won the ultimate battle for succession. However, some three decades later, when he unexpectedly fell ill and could no longer rule in person, Shah Jahan's adult sons fell to vying with one another, and with Shah Jahan, for control of the regime. ${ }^{134}$ It is said that Aurangzeb, well before the end of his reign, designated his eldest living son as the crown prince. But this was disputed by a younger son, who took up arms against his father in a failed attempt to overthrow him. To pre-empt the kind of difficulties that Aurangzeb had himself experienced earlier in his life, and perhaps even break with the long-standing pattern of rivalry marking the Mughal past, Aurangzeb left his sons a testament (vasiiyat-nāmah) offering advice on how to govern the empire following his death. ${ }^{135}$

\section{Imperial unity}

The problem of loyalty in the Mughal empire overlaps significantly with the problem of unity. Acquiescence is core to both. However, the loyalty in question is that of the ruling elites to the imperial regime (saltanat), whereas unity is oriented to the general population and its relationship to the body politic. The authors were obviously interested in the matter of elite loyalty. They were equally interested in the ways in which unity was conferred on the imperial polity ruled over by the Mughals (mamālik-i mahrūsah). This happened through fostering a sense of belonging and at the same time defending against fragmentation. That in turn had a bearing on the capacity of the Mughal world to withstand or organically adapt to structural changes and unexpected shocks.

Unity was predicated on being able to map, at least in the mind's eye, the geography of the Mughal world. The authors had that ability. Marshalled in negation, it helped them distinguish their own imperial polity from other countries and regimes. In so doing, the histories delineate the larger region of which the Mughals were an integral part. This is shown most clearly in the accounts of foreign rulers with whom the padshahs and their elites customarily exchanged gifts, correspondence, and embassies. The importance of polities abroad was such that one of the first acts of Babur after his victory over the Lodis was to send 'gifts to Samarkand and Khurasan and Kashghar and Iraq and acquaintances and intimates', and 'a lot of money to Mecca and Medina and Karbala and Najaf and Mashhad and most of the blessed

131 Mj319r; also Kt444.

132 Kt623-627, Mj330r-330v.

133 Kt655-662, Kt668-669, Kt671-675, Mj334r-335r, Mj336v-337v.

134 Kt679-745, Mj348r-366v, Mt29r-30v, Lt96v-114v.

135 Mt35r, Mt36r-36v, Mt41v-42r, Mt47r-47v. 
shrines, [which] made the deserving of these places cheerful'. ${ }^{136}$ By doing so, Babur declared to man and god the arrival of a new dynasty in Hindustan and the end of the Delhi sultans. In passing he also reveals to us the polities deemed worthy of consideration by the Mughals. Collectively these formed a distinct and coherent regional world. Indeed, that region is openly avowed in one of the histories in a section outlining 'the sultans who are contemporaries of Aurangzeb around the blessed world'. ${ }^{137}$ These sultans ruled over 'the mamālik of Rūm and Shām and 'Arabistān [,] the mamālik of Iran [,] the mamlakat of Bukhara [,] the vilāyat of Balkh [,] the viläyat of Kashghar [,] Mecca and Medina [, and] the bilād of Yemen'. ${ }^{13}$

This mapping from without had a counterpart in mapping from within. The histories document two mutually reinforcing perspectives on the latter. One stresses physical distances and travel times. So, in Aurangzeb's reign the Mughal world 'connected to the ocean to the eastern and western and southern sides, and on the northern side to the passes on the frontiers with Turan and [to] Ghazni on the frontiers with Iran. Both in longitude and latitude it is roughly about one year's travel. ${ }^{139}$ The other perspective looks at the Mughal world politically. This is done by describing the administrative units-șübah, mahall, sarkär, parganah-which made up the empire, the revenues (jamac, pishkish) generated by these units, and their past as independent or autonomous countries. ${ }^{140}$ It is paralleled by descriptions of the conquest of new areas by the Mughals and their capitulation to the mamālik-i mahrūsah. ${ }^{141}$ Note that, in contrast to some earlier writings, the geographies mapped by these histories do not convey a sense of India or the subcontinent per se. ${ }^{142}$ Rather, their picture of the Mughal world is of an agglomeration of geographically identifiable areas-most prominently, Hindustan, Panjab, Bengal, Gujarat, Kashmir, Kūhistān, Deccan-overlain by an imperial polity.

The governing architecture of this imperial polity extended beyond its northern India metropolitan heartlands of Hindustan to cover territories ruled autonomously. The governing architecture also extended beyond the imperial elites to intrude upon segments of the general population. Bearing witness to its extensive reach are the communal and sovereign duties, rights, and privileges-variously termed nāmus or tūrah-that, so the authors say, the Mughals

136 Lt69r. The accounts given in Mt21r and Mj317r differ slightly in the places listed.

$137 \mathrm{Mj} 381 \mathrm{r}$.

138 Mj381r-381v; also Lt4v.

$139 \mathrm{Lt} 4 \mathrm{v}$. Mj380r-380v details physical distances and travel times between specified places, and overall dimensions.

140 Kt57, Lt4v, Lt76r, Lt79r, Lt121r, Lt128v-129r, Mj380v-381r, Mj381v, Mt3v.

141 Kt429, Kt506-507, Kt509-515, Kt521, Kt533-535, Kt547-550, Kt552, Kt567-568, Kt576-578, Kt589-592, Kt595-596, Kt601-603, Kt606-607, Kt611, Kt650-653, Lt76r, Lt79r, Lt116r-116v, Mt25v-26r, Mt27r.

142 There is an insightful discussion on the changing notions of 'India' down to Akbar's time, and its elaboration during his reign, in M. Athar Ali, 'The perception of India in Akbar and Abu'l Fazl', in Irfan Habib (ed.), Akbar and His India (New Delhi, 1998), pp. 215-225. For a recent study arguing for the notion of India as a colonial construct, see Manan A. Asif, The Loss of Hindustan: The Invention of India (Cambridge, MA, 2020). 
recognized, upheld, and protected throughout the empire. ${ }^{143}$ Making this a reality depended on the exercise of Mughal hegemony. And the fount of that hegemony were the metropolitan and provincial capitals, alongside a large array of smaller fortresses (qil'ah), townships (qașbah), and redoubts (hișār). ${ }^{144}$ The mere presence of these settlements was an assertion and reminder of imperial rule over the general population. These were reinforced in a number of ways. The authors note the construction of monuments to Mughal rule in many of these settlements, above all the pleasure gardens, mausoleums, palaces, and mosque complexes from the reigns of Jahangir and Shah Jahan. ${ }^{145}$ Especial praise is lavished on the Shalimar garden near Lahore. 'It has been heard from travellers of the inhabited quarter of the world that no other garden [compares with it] in beauty and elegance. ${ }^{146}$ The widespread renown of these monuments undoubtedly served to popularize the ruling dynasty and its regime. But the mechanism considered most effective in bringing the padshah to the attention of the greatest number was the issuance in his name of the khutbah va sikkah, 'the sermon and the coin'. Such was its perceived importance that, as the histories remark over and again, new and would-be rulers made its implementation their priority. ${ }^{147}$

Other ways in which rulers intersected with the general population so as to engender a sense of a shared collective tended to be more episodic in nature. Exemplary justice is one of these. On crossing the river Chanab, local farmers implored Akbar to save them from the oppressive behaviour of a tax collector. 'As a warning to cruel revenue officials he slit [the tax collector's] throat with a dagger. ${ }^{148}$ When Jahangir heard that the son of a prominent rāi from Gujarat, who had recently come to court to pay his respects, was forcibly holding a Muslim woman in his home, Jahangir ordered 'the infidel ( $k \bar{a} f i r)$ be punished [in a manner] suited to the crime'. The punishment meted out, which is described in gory detail, was terrible and prolonged. ${ }^{149}$ Alongside instances of exemplary justice, the authors recount steps taken by rulers to institutionalize the administration of justice and render it accessible to the general population. Sher Shah is credited with taking the first steps in the 1540s. 'In court he treated indigenous and foreign (khvish va bigānah) justice equally and he saw

143 Lt67v, Lt90v. On possible links between nāmūs and Sharia, see Alam, 'Sharī'a, akhlāq and governance', p. 60. Türah derives from the Turkic töre (or törä or törü), which informed Mongol rule. Its varied meanings in the Mughal period are discussed in Mansura Haider, 'The Yasai Chingizi (Tura) in the medieval Indian sources', in R. C. Sharma et al. (eds), Mongolia: Culture, Economy and Politics (Indian-Mongolian Assessment) (New Delhi, 1992), pp. 53-62.

144 Kt541, Lt94r, Mj328v, Mj344v, Mt28v.

145 Kt638, Lt93v, Mj330r, Mj347, Mt28v, Mt37v-38r.

146 Mt38r.

147 For example, Kt430, Kt473, Kt490, Lt63v, Lt65v, Lt68v, Lt96v, Lt105v, Lt114v, Lt115r, Mt20v21 .

148 Kt588.

149 Mj330r. Based on a comparative historical analysis, an argument for the severity and frequency of capital punishment being inversely correlated to a regime's stability is presented in Richard Wand (ed.), A Global History of Execution and the Criminal Corpse (Houndmills, Basingstoke, 2015). 
all the people with one regard. ${ }^{150}$ Jahangir and Shah Jahan continued in that vein by establishing more detailed procedures and demarcating more carefully the jurisdiction of courts on different levels. This allowed for the possibility of appeal to higher courts, all the way up, so it is claimed, to the padshah. ${ }^{151}$

The provision of relief in times of crisis was a second dimension along which the Mughals occasionally took tangible form for the general population. Shah Jahan is lauded for this. In the early 1630s, after his forces had successfully raised the siege of Kabul by the Turani Nadhar Muhammad Khān, Shah Jahan appointed a judge to oversee the distribution of 'one lakh rupees from the treasury' to alleviate the suffering of the city's residents. ${ }^{152}$ At about the same time, the Deccan and Gujarat were struck by a great famine because of drought. Shah Jahan 'granted seventy lakhs rupees to the sufferers of dearth ... and reduced [taxation] by eighty crore dām from the crown lands, which is one-eleventh of the empire's territories'. ${ }^{153}$ Aurangzeb is also mentioned as taking decisive action to deal with dearth. ${ }^{154}$

Crisis relief overlapped with conspicuous bequests, often presented as charity for the needy or deserving. On entering Kabul early in his reign, Jahangir 'scattered a lot of silver to the spectators'. ${ }^{155}$ Shah Jahan handed out coined silver to the people when he reached Agra for his accession, ${ }^{156}$ and gave gems and silver to the needy and large sums of money to temples (mushkü). ${ }^{157}$ Later in his reign, land and cash were granted to those meriting it via the chief judge (sadr). ${ }^{158}$ Aurangzeb took to heart his father's example. When he learnt that in five months out of the year Shah Jahan used to make 'imperial bequests from the treasury of 79,000 rupees by way of the chief judge to the entitled ones', 'Aurangzeb ordered the chief judge and the mutașaddis of household matters to act according to the previous formula for [those] five months and for the other months as well to dispense 10,000 rupees each month to the deserving. ${ }^{159}$

These acts of exemplary justice, crisis relief, and charity resonate with the onus on ruling elites to facilitate the ease and prosperity of ordinary subjects, ${ }^{160}$ and are detailed with approval in the histories. That onus is also reflected in the infrastructural projects commissioned by several padshahs. Building on the successful initiatives of sher Shah, for which he is famed, ${ }^{161}$

150 Kt475.

151 In Jahangir's reign: Lt76r-77v, Mj329v-330r, Mt26r; in Shah Jahan's reign: Lt80r, Mt27v-28r. $152 \mathrm{Mj} 338 \mathrm{r}$.

$153 \mathrm{Mj} 339 \mathrm{r}$.

$154 \mathrm{Mj} 366 \mathrm{v}$.

$155 \mathrm{Mj} 330 \mathrm{r}$.

$156 \mathrm{Mj} 337 \mathrm{v}$.

157 Lt78r, Mt26v, Mt27r.

$158 \mathrm{Mj} 338 \mathrm{r}$.

159 Mj369v; also Mj378v.

160 This onus was vested in a tradition deeply embedded within India and the larger region to which it belonged. The tradition was a vehicle for preserving, debating, crafting, and disseminating knowledge deemed relevant to the art of governance by ruling elites. For details, see Aziz al-Azmeh, Muslim Kingship: Power and the Sacred in Muslim, Christian and Pagan Polities (London, 1997).

161 Kt476-477, Kt484, Kt637, Lt70r, Mj322r, Mt22r. 
Akbar, Jahangir, and Aurangzeb are reported to have maintained, improved, and extended the great thoroughfares (shāh-rāh) spanning Hindustan between Bengal and Panjab, and beyond, to Kabul and Kashmir. For the safety and convenience of 'travellers and wanderers', fruit trees were planted on both sides of the roads to provide food and shade; at regular intervals wells were dug to make water readily available; tall manärah were erected as milestones; and sarāis were constructed for lodging and protection. ${ }^{162}$ But perhaps the greatest single building project driven by concern for the "prosperity of the country and ease of the people' ${ }^{163}$ was Shah Jahan's canal, Shāh-nahr. When completed, it stretched 'from the place with the Ravi river emerged from Kūhistān' to Lahore. In crossing Panjab, it irrigated 'farms and gardens' and secured water supplies for the area's capital. ${ }^{164}$

The histories make clear that the imperial elites seldom involved themselves directly in the affairs of the general population. This limited their capacity to influence how the unity problem was addressed, and that makes the exceptions worthy of note. The exceptions highlighted turn on the plural nature of the padshah's subjects. ${ }^{165}$ According to the author who tackles the issue most openly, plurality is a fact of social life, brought into being by god and finding expression in 'a variegated world and colourful mortals [and] various doctrines (mazāhib) and different dispositions (mashārib)'. ${ }^{166}$ Because 'each sect thinks their tradition divinely ordained and inescapable, plurality is thus a potential source of disunity. 'They imagine the religion and customs (din va $\left.a^{\prime} \bar{i} n\right)$ of others as mere trifles [and] ascribe divine mercy [solely] to their own condition. And they imagine the disagreeable annoyance of their religion and the execution of their own customs as the assent of [god] ... The qualities of the ordinary [adherents] of each group are such that, [since] they do not understand the basics, they think of fanaticism (tacassub) as worship ('ibādat). ${ }^{, 167}$ That plurality does not in practice translate into disunity is thanks to 'the special ones (khāsșān) of each community'. Possessing knowledge and wisdom, 'they do not conceive of the mercy of [god] as specific to a community'. Rather, 'like sunlight [and] rain ... they conceive of [god's mercy as belonging to] all communities. And because heavy burdens result from bigotry and obduracy, they live with friends in harmony and with enemies without

162 In Sher Shah's reign: Kt477; in Akbar's reign: Kt549, Kt579; in Jahangir's reign: Kt637, Mj330r; in Aurangzeb's reign: Mj378v.

163 Lt93r.

164 Lt93r-93v, Mt28v.

165 Muzaffar Alam has argued that Sharia in Mughal India, especially during Akbar's and Jahangir's reigns, was understood by many among the ruling elites in a pluralistic manner, both in practice and in theory. This argument is developed in a series of essays: M. Alam, 'Shari'a and governance in the Indo-Islamic context', in David Gilmartin and Bruce B. Lawrence (eds), Beyond Turk and Hindu: Rethinking Religious Identities in Islamicate South Asia (Gainesville, FL, 2000), pp. 216-245; M. Alam, 'Akhlāqī norms and Mughal governance', in Muzaffar Alam, Françoise 'Nalini' Delvoye and Marc Gaborieu (eds), Making of Indo-Persian Culture: Indian and French Studies (New Delhi, 2000), pp. 67-95; Alam, 'Sharī'a, akhlāq and governance', pp. 26-80.

166 Kt51; also Kt49.

167 Kt51. 
quarrel. ${ }^{168}$ These ideas strongly echo the philosophy of șulh- $i$ kull ('universal peace'), which crystallized in Akbar's reign and was closely associated with his 'House of Worship'. ${ }^{169}$ The histories gloss sulh-i kull as a purposeful response to the fact of plurality. Akbar believed god 'bestowed on people differences in disposition and variety in doctrine', and 'viewed with kindness the communities of mankind and the classes of people'. In keeping with this divine dispensation, Akbar urged 'Muslims and Hindus and Zoroastrians and Christians and other religious people (ahl-i mazāhib) to exist with one another in a state of sulh-i kull' so that 'anyone may worship the creator according to his own religion and customs. ${ }^{170}$

It is implied that the Mughals were acutely conscious of plurality as a basic reality of their world. ${ }^{171}$ With the requisite knowledge ( $\mathrm{ilm}$ ), and an attitude consonant with the corporatist sulh-i kull, plurality could be managed to facilitate cohesion of the imperial polity at large. This is reflected in the near absence of discussion of the jizya, the poll tax on non-Muslims communities traditionally levied by Islamic rulers. The one occasion on which it is discussed concerns its abolishment by Akbar. That happened, so the authors say, because the great wealth 'in the treasuries' of the regime and the obedience of 'all the rājās and rāis' meant there was no longer any rationale for the jizya. ${ }^{172}$ Moreover, abolishing it harmonized with Akbar's purported opinion that 'the duty of padshahs is not to foster religious antagonism and dispute [but] to treat well the slaves of god... and confer special favours on everyone equally'. ${ }^{173}$ Relatedly, the histories display no more than (at best) a passing interest in conversion to Islam or in extending the reach of Sharia. ${ }^{174}$ Islam and Sharia as doctrines have no significant place in their interpretations. This is not to say, however, that religion or, perhaps more accurately, orthodoxy were unimportant. So, generic Islamic norms seem to underpin many of the judgements of the authors regarding the actions of particular individuals and communities. The authors also show keen awareness of the multiplicity of mazāhib and mashārib among the subject population. But notwithstanding the regime's formal adherence to Ḥanafi Islam, these

168 Kt51.

$169 \mathrm{Kt536-540,} \mathrm{Mj329r-329v.} \mathrm{On} \mathrm{the} \mathrm{ideology} \mathrm{of} \mathrm{șulh-i} \mathrm{kull} \mathrm{as} \mathrm{formulated} \mathrm{by} \mathrm{Abū} \mathrm{al-Fadl} \mathrm{and}$ Akbar, and criticisms by contemporaries and near-contemporaries, see M. Athar Ali, 'Sulh-i Kul and the religious ideas of Akbar', in his Mughal India: Studies in Polity, Ideas, Society and Culture (New Delhi, 2006), pp. 158-172; Shireen Moosvi, 'The road to Sulh-i Kul: Akbar's alienation from theological Islam', in Irfan Habib (ed.), Religion in Indian History (Delhi, 2007); Saiyid Athar Abbas Rizvi, 'Dimensions of Șulh-i Kul (Universal Peace) in Akbar's reign and the Șüfi theory of Perfect Man', in Iqtidar A. Khan (ed.), Akbar and His Age (New Delhi, 1999), pp. 3-22; Syed Ali Nadeem Rezavi, 'Religious disputations and imperial ideology: The purpose and location of Akbar's Ibadatkhana', Studies in History 24:2 (2008), pp. 195-209.

$170 \mathrm{Kt} 536$.

$171 \mathrm{Kt} 51-55$.

$172 \mathrm{Kt535}$. Contemporary views on jizya are examined in Satish Chandra, 'Jizyah and the state in India during the seventeenth century' and 'Jizya in the post-Aurangzeb period', in his Essays in Medieval Indian Economic History (New Delhi, 1987), pp. 305-324, 346-353.

$173 \mathrm{Kt536.}$

174 For example, Mj372v, Mj378v. 
traditions are treated in a broadly agnostic and even-handed manner. Money grants were made to both temples and the ulema on the accessions of Shah Jahan and Aurangzeb. ${ }^{175}$ Akbar is mentioned as giving material help to the Sanyansis (țāi ifa-i Sanāsiyān) of Patiala who had been quarrelling with the local Muslim dervishes (fugarä $\bar{a}^{3}$-yi Muslimin) and suffered at their hands, ${ }^{176}$ while Aurangzeb ordered the suppression of the Afghans of Kabul who "had broken his nāmūs' by desecrating the 'Alī Masjid and a Hindu temple (but-khānah). ${ }^{177}$

Much is made in the histories of margins being important to how the Mughal world was conceived by its elites, which in turn influenced how they addressed its unity. Internal margins were defined by areas that lay beyond the imperial purview and yet were surrounded by territories under Mughal control. These appear to have been relatively small in scale, with rulers classed as independent (mustaqill) or exercising independence (istiqlāl). They existed outside the architecture of the empire and were seemingly either tolerated or ignored. Greater prominence is given to margins forming the external borderlands or frontiers (marz, sar-hadd, hudūd) of the imperial polity. These come into view most forcefully in reports of invasions, or the threat of them. Thus, unsurprisingly, margins are central to how the histories interpret the rise of the Mughals, which, of course, began with an invasion. In the authors' narrative, their origins lay within the area of Turan ( $m \bar{a}$ wară' al-nahr), in today's Central Asia, where Babur was born and brought up. But the actual campaigns towards the Indus and Lahore were waged from his subsequent base in Kabul. Babur's goal was the conquest of what is termed Hindustan (or more rarely Hind), which he attempted on several occasions. ${ }^{178}$ Following his eventual success, Mughal history is presented by all four authors as anchored in this area, in the upper half of the Indian subcontinent. ${ }^{179}$

The northwest frontier from which Babur hailed is portrayed as a continuing source of instability for Hindustan long after the first Mughal padshah's death. We are told of a plot by Muhammad Zamān who, on being ejected from Badakhshan, sought to wrest Kabul from Akbar's empire. ${ }^{180}$ Later, after learning of Jahangir's death, Nadhar Muhammad Khān attempted to capture Kabul from Balkh. ${ }^{181}$ Though both failed in their aims, their actions served

175 Lt78r, Lt115v, Mt26v-27r.

$176 \mathrm{Kt} 603$.

177 Mt30v.

178 Kt425-434, Lt65v-69r, Mj315v-317v, Mt20v-21v.

179 While there is no denying the cardinal significance of Hindustan in the authors' conception of the Mughal world, they leave its geographical parameters ill-defined. Indeed, these parameters appear to shift from topic to topic, and over time. Though we still lack a proper conceptual (or even intellectual) history of Hindustan, based on a fresh examination of Tärikh-i Firishta, which is considered the first comprehensive history of Hindustan, we now have a useful study of how the area was understood in circa 1600. See Manan A. Asif, The Loss of Hindustan: The Invention of India (Cambridge, MA, 2020). This study also details the fate of Hindustan as a concept during the period of the Company and British Raj.

$180 \mathrm{Kt} 566$.

181 Lt80v-82r, Mj338r, Mt28r. 
as reminders of a geographical vulnerability which the ruling elites ignored at their peril. This accounts for the strategic importance accorded by the authors to Lahore as a gateway between Hindustan and Turan by way of Kabul. Adequately fortified, it shielded Hindustan and, at the same time, furnished a base for Mughal campaigns to the frontier. Not doing this, however, portended the opposite: an under-protected Lahore, because of its luxuries and supplies, would inevitably draw towards Hindustan enemies from the frontier. ${ }^{182}$ Abutting this frontier were the borderlands with Safavid Iran. Though after Humayun's return in 1545 no invasions emanated from there over the period covered by the histories, its possibility was never dismissed, not least because of the very fact of Humayun's restoration. The authors flag that possibility by noting the sustained interest of Mughal elites in the military and political situation of Iran under the Safavids. In part, this was satisfied by official envoys to the Safavid court who brought back valuable intelligence for the padshahs; ${ }^{183}$ in part, it was satisfied by Mughal officials posted to the borderlands, like Khavāș Khān sent by Shah Jahan to Qandahar, who were there not just to guard and administer the area but also to keep informed about the [Safavid] shah because of [his] proximity to the border'. ${ }^{184}$ The area's vulnerability is demonstrated by the fate of Qandahar. This, the histories testify, was repeatedly fought over by the Mughals and Safavids down to Shah Jahan's reign (after which it remained in Safavid hands). ${ }^{185}$ Similar reasons caused the Mughals to worry about the frontier on the other side of Hindustan, in the east. This extended into the areas of Bengal, Bihar, and Odisha, whence several invasions were launched into the empire's heartlands. By far the most significant, and deemed formative for later Mughal history, were the series of military campaigns led by Sher Shah. ${ }^{186}$

So, several of Hindustan's frontiers and borderlands figure in the histories because of their potential to destabilize the imperial regime. Other areas on the margins of the Mughal world did not pose such a threat but nevertheless attracted increasing attention over time. The authors explain this as a reaction to unexpected developments. In one typical pattern, the padshah would despatch officials to remind local rulers of the need to obey the imperial writ and warn them of the consequences of failing to do so. In a second pattern, armies would be sent to suppress uprisings and enforce pre-existing arrangements. A combination of these patterns is marshalled to account for Mughal expansion into Gujarat in Humayun's reign, ${ }^{187}$ Kashmir in Abkar's reign, ${ }^{188}$ and Assam in Aurangzeb's reign. ${ }^{189}$ The Deccan falls into this category, too. According to the histories, of all such marginal areas, the Deccan most

$182 \mathrm{Kt} 484$.

183 For example, Kt633-644, Mj374v.

184 Lt92v.

185 Lt76r, Kt590-591, Lt77v, Mj334r, Lt90v-93r, Mj341r-341v, Mj342v, Mj344v-345r, Mj346r. 186 Mt22r, Lt69v-70r, Mj318-320v, Mj321v, Kt444-450, Kt470-473.

187 Kt442-444.

188 Kt567-568, 573-578; also Mj322r.

189 Mj369r, Mj377v. 
exercised the Mughal elites once their regime in Hindustan had been consolidated. Hegemony over this area was initially established under Akbar. What began as an entanglement in a succession dispute ended with part of Nizām Shāh's territories being incorporated into the regime. In addition, the 'Ādil Shāh rulers of Bijapur and the Quṭb Shāh rulers of Golconda, while retaining autonomy in their internal affiars, formally became Mughal tributaries and tax collectors. ${ }^{190}$

The authors narrate an unstable dynamic between the Mughal regime and the Deccani rulers after Akbar. Agreements entered into were frequently observed in the breach, necessitating repeated Mughal interventions in the reigns of Jahangir, Shah Jahan, and Aurangzeb. Each intervention follows the same basic script. News would reach the Mughal court of a breakdown of order in the Deccan, most commonly seen as uprisings or rebellions against the empire and the oppression of ordinary people. This was often accompanied by local rulers being remiss in paying their annual tribute (pishkish) or remitting their taxes. In response, a military campaign would be launched from the north to warn and chastise (tanbih, mälish). Order would be restored and the defiant ruler humbled. The Mughals might also take into direct control further territories in the Deccan and seal new matrimonial ties with the defeated ruler's family. In this way, the area and its rulers reverted to the imperial fold. A few years later, however, the expected tribute or taxes would fail to reach the central treasury, disobedience would become rife, or locals would act to undermine or break free of the empire's hegemony. In due course, a Mughal army would again be sent into the Deccan to put the situation to rights. And so the cycle continued. ${ }^{191}$ It was not until the 1680 s that a serious attempt was made to replace this cycle with a fresh dynamic. Frustrated by the rulers of Bijapur and Golconda not giving due support to Mughal officials in the Deccan and by their inability to keep the troublesome Marathas in check and maintain order, ${ }^{192}$ the authors report that Aurangzeb decided on a major offensive against the area's rulers. Over the next few years, the Mughals ground out victories, culminating with the capture of Bijapur and Golconda. ${ }^{193}$ Then, in place of the pre-existing dynamic, Aurangzeb annulled Deccan's autonomy and, so the histories claim, integrated the area into his regime's centralized system of revenue and political administration. ${ }^{194}$

Stepping back from the details, the views above associate the outside world with invasions and conflicts. These had an important bearing on the cohesion of the imperial polity. But the histories do not stop there; the outside world had a bearing on cohesion for other reasons as well. It offered those who had been defeated the prospect of sanctuary. Iran is proverbial in that regard.

190 Kt601-611.

191 In Jahangir's reign: Mj331r-332v, Mj333v-334r; in Shah Jahan's reign: Kt674, Kt678, Lt79r, Lt85r-90v, Lt95v-96r, Lt121r-124r, Lt94r-95v, Mj338r-339v, Mj340v, Mj346v-347r; in Aurangzeb's time: Mj372r-372v, Mj381v.

192 Lt119v-120v, Mt32v.

193 Lt120v-121r, Lt124r-130v, Mt32v-34r.

194 Lt121r-121v, Lt127v, Mj381v. 
This drew strength from the positive manner in which Humayun's sojourn there was remembered. ${ }^{195}$ The memory did not just cement Iran as a quintessential place of refuge for Mughal elites on the run; it also offered hopes of a homecoming. The authors mention several who followed Humayun's example, most notably Shah Jahan's son Muhammad Murād Bakhsh (who returned) and Aurangzeb's son Muhammad Akbar (who died there in exile). ${ }^{196}$ The Deccan, too, is noted as a place where opponents of the padshah took refuge or went into exile. ${ }^{197}$ Its attraction stemmed partly from the area's many local rulers who themselves were resentful of the Mughal empire's presence. But because of undertakings made to the padshah in exchange for a free hand in their internal affairs, the principal Deccani rulers-the Nizām Shāh, 'Ādil Shāh, and Quṭb Shāh sultans-tended to exercise caution in dealings with rebels or rivals fleeing into their territories from the north. The histories convey the sense that support from these rulers was seldom forthcoming unless the arrival of the opponent coincided with their own plans to overthrow Mughal hegemony. This calculus began changing, however, with the rise of Marathas power in the Deccan from the middle of the seventeenth century. It would appear that the Maratha leaders never entered into a durable agreement with the padshah or his tributaries. Rather, they are portrayed as operating largely beyond the purview, let alone control, of the Mughals. This raised the profile of the Marathas and, for the padshah's opponents, made them increasingly credible as allies. ${ }^{198}$

Refuge and exile abroad intersected with diplomacy. Diplomacy, as the authors articulate it, was the means by which the Mughals formally recognized and dealt with elites elsewhere. In the process, they defined themselves and their conception of the Mughal world. Diplomacy manifested itself in a variety of ways. The histories frequently refer to the exchange of gifts, correspondence, and embassies between rulers. These bear witness to systemic linkages between the Mughal regime and a host of regimes abroad. Intriguingly, none of these was located to the east or to the south of the empire; all were situated within areas of Eurasia where Persianate or Islamicate norms prevailed. The most intensive relations seem to have been with rulers in Iran and Turan, whose territories abutted those of Mughal empire to the west and northwest. Over the period covered, the number of diplomatic exchanges with these rulers significantly outnumber those with any others. ${ }^{199}$ Iran is depicted as

195 Kt448-457, Lt69v-70v, Mj319r-321r, Mj322v-323v, Mt21v-22v. This positive manner suggests that the tensions between Humayun and his Safavid host Shah Țahmāsp, documented in earlier works such as Mihtar Jauhar's Tadhkirat al-wāqi āt, had been forgotten or effaced by the end of the seventeenth century.

196 On Muḥammad Murād Bakhsh: Lt81v, Mt28r; on Muḥammad Akbar: Lt129v-130r, Mt34r, Mt35r, Mt37r.

197 Turan is mentioned as an area to which opponents escaped, as are Bihar, Bengal, and Gujarat (in the early Mughal past). But accounts of these in the histories are few and fleeting in comparison with Iran and the Deccan.

198 For example, Kt528, Lt119v, Mt32r, Mt35r.

199 In Babur's reign: Lt69r, Mj317r, Mt21r; in Humayun's reign: Kt454-457, Lt70v, Mj322v-324v, Mt22v; in Akbar's reign: Kt563, Mj327v; in Jahangir's reign: Kt633-634, Mj333r-333v; in Shah Jahan's 
encompassing, or being synonymous with, 'Irāq and Khurāsān. These areas were governed by a cohesive regime headed by a shah, who is usually designated by the relatively humble vālī, or very occasionally farmān-ravā or dārā. In contrast, the picture of Turan is more fragmented. While Samarkand and Kashghar are mentioned, ${ }^{200}$ Turan for the authors primarily meant Balkh and Bukhara. These places were at times ruled over by their own separate $v \bar{a}$ liss, at times jointly by a single overarching vāli. ${ }^{201}$ Looking farther afield, there were rulers of regimes clustered in and around Arabia, the Persian Gulf, and the Red Sea with whom the Mughals kept up relations, albeit at a lower intensity. So, we see talk of the sharifs of Mecca and Medina, ${ }^{202}$ the imām of Yemen, ${ }^{203}$ the hākim of Hadhramaut, ${ }^{204}$ the hākim of Habshah (Abyssinia), ${ }^{205}$ and the hākim of Basra. ${ }^{206}$ Most distant of all in the shared diplomatic world of the Mughals was the Ottoman ruler, generally referred to as qaișar or farmān-rava $\bar{a}^{207}$

Though gifts and correspondence between rulers could be conveyed by couriers, more often this appears to have been done by envoys at the head of official embassies. ${ }^{208}$ The histories recount embassies passing back and forth between rulers on a regular basis and being a common presence at court. Led by the foreign ruler's personal representative, variously termed illchī, firistādah, safir, or rasūl, the suggestion is that every help and courtesy was extended to them while in Mughal territories. By the same token, the Mughals took a keen interest in the treatment of their envoys abroad. ${ }^{209}$ The diplomatic norms are at their most explicit in the account of an Ottoman embassy headed by Saiyid Muhyī al-Dīn to Shah Jahan's court in the early 1650s. Its details exemplify the typical pattern. ${ }^{210}$ The envoy was an honoured guest from the moment he reached Mughal territory until his departure. He travelled to court where he remained at the padshah's pleasure. On given permission to leave, he went laden with valuable gifts, carefully enumerated and costed, for his ruler (and often for himself), as well as with money to cover the expenses of his journey. Letters from the Mughal side to his own, however, were not normally consigned to him. Rather, they were sent in the hands of a courier specially commissioned by the Mughals or entrusted to an envoy

reign: Lt92r-92v, Mj338v, Mj339v, Mj341r, Mj341v; in Aurangzeb's reign: Mj366v-367r, Mj367v, Mj370r, Mj370v, Mj374v.

200 Lt69r, Mj317r, Mj327v, Mt21r.

201 Balkh: Mj339v, Mj340r, Mj366v, Mj370v, Mj377r; Bukhara: Mj368r, Mj368v, Mj370r, Mj370v, Mj377r; Turan: Kt563, Kt567, Mj338r.

202 Lt69r, Mj317r, Mj364r, Mj371r, Mt21r.

203 Mj370r, Mj370v, Mj371r.

204 Mj371r.

205 Mj371r.

$206 \mathrm{Mj} 368 \mathrm{r}$.

207 Mj345r-345v, Mj345v, Mj346r, Mj346v.

$208 \mathrm{Kt} 563$, Mj345v, Mj346v, Mj367v, Mj370v provide insights into the Mughal practice of conveying diplomatic gifts and correspondence.

209 For example, Kt633-634, Mj374v.

210 Mj345r-345v. Mj346r and Mj346v give an account of another Ottoman embassy to Shah Jahan's court a few years later which followed a similar pattern. 
leading a Mughal embassy to the foreign ruler's court. This exchange of correspondence, gifts, and embassies between the courts of the region was part-and-parcel of an ongoing circulation of valued objects, information, ideas, and people between the ruling elites of an array of polities. The picture is one of mutually constitutive polities in a shared ecumene, stretching in one direction from the eastern Mediterranean to the Bay of Bengal, and in the other from the shores of the Arabian Sea to those of the Caspian.

The Mughal world's unity is presented as strongly bound up with the character and actions of the regime's allies and opponents. For the initial phase of Mughal history, the authors stress the formative role played by foreign allies. Thus, in Babur's eventual conquest of Hindustan, encouragement was received from several of Sultan Ibrahim Lodi's umara $\bar{x}$ who had turned against their ruler because of his disrespectful behaviour towards them in court early in Ibrahim's reign and the later imprisonment and murder of two of their number. ${ }^{211}$ The first steps in the recovery of Hindustan by Humayun were, it is said, indebted to his alliance with the Safavids. On his return in 1545, he came at the head of an army to which Shah Tahmāsp had contributed 'a tūmār of twelve thousand cavalry and the command of [his son] prince Mīrzā Murād ... with a țūmār of supplies ... And there were nearly twenty-five [of his] umarā' ... in that army. And beyond that, 300 personal cuirassiers were also assigned to [the army]. ${ }^{.12}$ In exchange, Humayun undertook 'to hand over Qandahar fort to the Shāh's people after [their] victory'. ${ }^{213}$ Though considerable progress was made by Humayun, at his death the reconquest of Hindustan proper from the Suris and their successors remained a desiderata. ${ }^{214}$ One of the principal blockages was Sikandar Shāh Sūr, who continued to resist by organizing Afghan forces against the Mughals. Very early in Akbar's reign, an army was despatched to suppress him. ${ }^{215}$ Confronted by superior forces and disheartened by news of Mughal successes elsewhere, Sikandar submitted, begging Akbar to forgive him his sins. The Mughals did not just forgive him; they assimilated him and his family into their elites, bringing to heel a dynasty whose head had once been their padshah's most fearsome and successful enemy. ${ }^{216}$ Granted a jāgir, 'it was decreed that Sultan Sikandar will go towards Patna [and], having taken that country from the Afghans, become [its] mutasarrif, and his son will come before [Akbar and] undertake service'. ${ }^{217}$ Thereafter, while no further alliances with foreign rulers are documented in the histories, the Mughals were willing to give sanctuary to leading members of regimes in their near vicinity, particularly to those recently deposed. ${ }^{218}$

Opponents are, of course, the logical counterpart of allies. But given how the histories articulate them, the distinction between the two in the Mughal

211 Kt415-417, Kt425-429, Lt63v-64r, Lt67r-68v, Mj296v, Mj316r-316v, Mt19v-20v.

$212 \mathrm{Mj} 323 \mathrm{v}$.

213 Kt457; also Lt71r, Mj324r, Mt23r.

214 Kt488-490, Lt72v, Mj325v-326r, Mt24r-24v.

215 Kt499, Lt74r, Mj326v.

216 Kt499-500, Lt74r, Mj326v-327r, Mt24v.

$217 \mathrm{Kt} 500$.

218 For example, Kt564-565, Mj377r-377v. 
past is far from clear. This ambiguity stems from the way in which opponents are categorized. ${ }^{219}$ One type was peopled by those, like Akbar's official Adham Khān and the Golconda sultan Abū al-Ḥasan Quṭb Shāh, ${ }^{220}$ who remained members of the Mughal elites even as they opposed the reigning padshah. They were thus potentially reconcilable (mustamāl) and amenable to reincorporation into the body politic. As their disloyalty did not alienate them from the Mughal empire, they fall within the ambit of the loyalty problem, discussed above. That does not apply, however, to the second type of opponent detailed in the histories who stood resolutely apart from the Mughal empire. It is declared repeatedly that opponents were a priori misguided and ignorant. But those of the second type were, in addition, morally debased. The epithets typically used to describe them-'damned' (mal'ūn, mardūd), 'impious' (kufr, bad-kīsh, maqhūr), 'malevolent' (bad-andīsh, khiläf-andish, munqalib-mutahavvir)-exemplify that judgement. It is also exemplified by their purported tendency to indulge in trickery, deceit, and betrayal to achieve their ends. They are interpreted by the authors as irreconcilable enemies with whom a pragmatic, constructive arrangement was in the longer term unachievable. This left warfare and coercion as the sole practical means of dealing with them, the ultimate goal being their eradication (istișāl, qam', qal').

The authors recount that most of the adversaries implacably opposed to the Mughals either hailed from Afghan or Maratha communities, or had close ties to them. Afghans and Marathas are portrayed as notoriously troublesome. This is in contrast to the more pliable, dependable Rajputs, the only other ethnic group to figure prominently in the histories. The Afghans are said to have posed a challenge to the unity of the imperial regime from its very inception. This was due in part to the Afghan umara $\bar{a}^{3}$ who apparently ruled much of Hindustan under the Lodis. Even after Babur's armies captured Delhi and Agra, these Afghan elites 'had in [their] control many countries and fortresses far and near. ${ }^{221}$ Though Babur's power and policies managed to temper their opposition over time, ${ }^{222}$ the Afghans remained a disruptive force. This was rooted in '[their] fault ... that they do not agree among themselves', ${ }^{223}$ which made them difficult to govern. It follows that key to the consolidation of the Mughal regime under Akbar was the removal of the Afghan threat from the heartlands of the empire. While this threat was eventually curbed, it was

219 The discussion here may be usefully compared with earlier views on the relationship between an individual's political acts and his moral nature, and on his inherited, as opposed to acquired, characteristics. For details, see Irfan Habib, 'Barani's theory of the history of the Delhi Sultanate', India Historical Review 7:1-2 (1980-81), pp. 99-115; Harbans Mukhia, Perspectives on Medieval History (New Delhi, 1993), pp. 13-16, 21-23, 34-35; Alam, 'Shari'a and governance in the Indo-Islamic context', pp. 225-226; Alam, 'Sharī'a, akhlāq and governance', pp. 41-42; Ali Anooshahr, 'Author of one's fate: Human agency and fatalism in Indo-Persian histories', Indian Economic and Social History Review 49:2 (2012), pp. 197-224; Anooshahr, 'Mughals, Mongols, and Mongrels', pp. 559-577.

220 Kt509-510, Lt124r-129r.

$221 \mathrm{Mj} 317 \mathrm{r}$.

222 Kt431-434.

$223 \mathrm{Kt} 468$; also Mt39v. 
never fully excised. ${ }^{224}$ Henceforth, the histories locate the Afghan zones of operation in the north and northwest, in and around Kūhistān, Panjab, and Kabul. From Shah Jahan's reign, these areas were populated by 'a beehive of Afghans ${ }^{225}$ and dominated by tribes ( $q a b \bar{a}{ }^{\prime} i l$, ulüs) such as the Yūsufzāi and the nomadic, anarchic Ghilzāi. ${ }^{226}$ They are variously described as 'cowardly', prone to 'fitnah va fasād', 'permanently wrong-headed and irrational', 'wicked and short-sighted'. ${ }^{27}$ From among the Afghans at large, the one who towered above all others in the authors' eyes for his importance to Mughal history is Sher Shah. His genius, as they saw it, was to unify his undisciplined brethren and rule constructively. ${ }^{228}$ Though this entailed the defeat of Humayun and the replacement of Mughal dominion in Hindustan by that of the Suris for much of the 1540s and 1550s, the reign of Sher Shah is generally, and for an Afghan exceptionally, viewed with favour. Indeed, the authors are effusive in praising Sher Shah's talent for administering government, the military, and justice. ${ }^{229}$ This is reflected in his material achievements-rationalizing territories, institutionalizing the bureaucracy, building sarais and planting trees to facilitate transport and travel, improving communications by establishing post houses, setting up garrisons and villages of Afghans for security ${ }^{230}$-which are remarked upon as significant not just for the period of Suri dominion but also for the Mughals after their restoration in Hindustan. ${ }^{231}$

Comparably resolute opponents emerged in the Deccan as well. However, these opponents do not appear to have impressed themselves on the Mughal elites until the latter seventeenth century. Posterity labels them the Marathas, though the histories use this term on only one occasion, when describing their leading figures as belonging to 'the Maratha Bhonsle community (qaum), ${ }^{232}$ to whom various 'tribes (qabā'il)' were attached. ${ }^{233}$ These figures are held responsible for repeated fitnah and fasād in the Deccan, and roundly condemned as seditious. ${ }^{234}$ The Maratha threat was embodied for the authors in a succession of leaders from the same family. Considerable efforts were made by the Mughals to tame or suppress them, though success

\footnotetext{
224 Kt560-563.
}

225 Lt87v, Lt115v.

226 Kt560-563, Mj376r-376v, Mt39v.

227 Lt115v, Mj376r-376v, Mt30v, Mt39r.

228 This was decidedly not the opinion of Abū al-Faḍl, who considered Sher Shah a mere rebel and insisted on addressing him in the diminutive form Sher Khan. Indeed, posterity might well have remembered him in that manner were it not for 'Abbās Khān Sarvani's Tuhfah-i Akbarshāhī, whose focus is Sher Shah's reign. See Nizami, On History and Historians, pp. 157, 233-234; Mukhia, Perspectives on Medieval History, p. 20.

229 Kt467, Kt475-476, Lt70r, Mt22r.

230 Kt476-477, Lt70r, Mj322r, Mt22r.

231 Suri dominion produced a second prominent figure, Hemu (or, as he is usually called in the histories, Hīmūn Baqqāl, 'the grocer'). He was a Hindu and became the effective ruler in northern and eastern India for a time, seriously threatening the Mughal restoration in Hindustan. Kt485-490, Kt495-498, Lt70v, Lt73r-74r, Mj325r-326v, Mt22v, Mt24v. 
remained elusive, down to the close of the histories. The existence of the Marathas is not even hinted at until early in Shah Jahan's reign, when the first of their leaders, Shāhjī, suddenly bursts onto the scene in the Deccan. He comes across as a mercurial figure. At times he is fighting alongside the Mughals as a mansabdār; at times he is fighting against them in alliance with other opponents of the empire, while ruling in his own right. ${ }^{235}$ Shah Jahan imagined a resolution had been found when, with Mughal hegemony in the Deccan re-established, the apologetic 'Ādil Shāh undertook to govern the area on the padshah's behalf, and 'accepted that he will either eradicate the fitnah-jū Shāhjī or make [him] his servant'. ${ }^{236}$ Thereafter, Shāhjī settled down as a zamindār with a jāgīr to his name. ${ }^{237}$ But his son and successor Shīvājì had other ideas. Starting off as Shāhjī's deputy in his parganahs, Shīvājī led uprisings against 'Ādil Shāh's regime and managed to seize territory in the Konkan, keeping his enemies successfully at bay. ${ }^{238}$ These actions eventually provoked a military response from the Mughals under Aurangzeb. However, its outcome seems to have been inconclusive, ${ }^{239}$ and Shivāji continued to cause trouble for the Mughals. ${ }^{240}$ After his death, Shìväjì's mantle was picked up by his son Sambhājī, who inherited the late Shīvājī's army and supplies, and the zeal of his chiefs. ${ }^{241}$ Sambhajjì's opposition to the Mughal empire is supposed to have convinced Aurangzeb to embark on a comprehensive conquest of the Deccan. As detailed in the histories, that set in motion a chain of events which ended with the termination of autonomous rule in the area and its assimilation into the Mughal regime. ${ }^{242}$

The presence of irreconcilable Afghans and Marathas resonates with the more commonplace motif of rebellions, uprisings, and disorder. Dealing with these was, according to the authors, a core task of sovereign governance, and a test of the Mughal elites to pre-empt or defend against the imperial polity's fragmentation. They were normally up to the challenge, aided not least by their inherited, collective knowledge of such matters. But the authors also recount moments of more generalized instability or crisis which risked the dissolution of the empire as a whole. In retrospect, these moments often coincided with fateful turning points in the Mughal past. On the difficulties being overcome, as they always were, the padshahs were then free to devote themselves to implementing policies which served to strengthen the regime and improve the lot of their subjects.

So, we read that upheaval was the rule in Hindustan at the time of Babur's conquest. 'Most of the umarā’ turned [against Sultan Ibrāhīm Lodi] and around the country there arose fitnah va fasād and on every side the servants of the

235 Lt89r-90v, Lt121r, Lt122v, Mj3339r, Mj340v.

236 Lt121r.

237 Lt121v.

238 Lt121v-123r.

239 Lt120r, Lt123r-124r, Mj368v, Mj370v-372v, Mj373v-374r, Mj375r-375v.

240 Lt124r.

$241 \mathrm{Lt} 124 \mathrm{r}$.

242 Lt120v. 
sultan rebelled. ${ }^{243}$ However, 'through well-directed measures, [Babur] cleansed the refuse of rebels from the area of the mamälik. ${ }^{244}$ This facilitated the relatively peaceful accession of Humayun. ${ }^{245}$ As already seen, his reign was interrupted by Sher Shah, who, in defeating the Mughals, unsettled Hindustan. Sher Shah thus had to expend 'great effort during his rule ... to cleanse the mulk of the rubbish of the rebels'. ${ }^{246}$ Humayun's decision to invade after his return from exile was prompted by news that 'in every part of Hindustan Afghans have raised the flag of rule [and] each one wields power, and in Hind there have emerged kings of [different] communities. In these circumstances [Humayun]... set forth for Hindustan. ${ }^{247}$ The regime he left behind for Akbar on his unexpected death was far from secure. When Akbar ascended the throne, 'there was no territory in [the padshah's] control apart from the sarkār of Panjab'; Hindustan was mostly in Afghan hands. ${ }^{248}$ Even after 'all the territory of Hindustan was cleansed of the contamination of opposition, ${ }^{249}$ much of it passed not into Akbar's hands but into those of 'the old chief umara $\bar{a}$, who, buttressed by their own retinues, treasuries, and subjects, were prone to revolt. ${ }^{250}$ It is only when he ended his minority and took hold of the reins of power himself that Akbar was able to 'order their reform and punishment and eradication', ${ }^{251}$ and so 'remove their sedition'. ${ }^{252}$

In the decades that followed, the Mughal world is depicted as blessed with ease and prosperity. But rebellions, uprisings, and disorder had not become things of the past. They reappear in force during the de facto rule of Nūr Jahān and her clique. 'There were great revolts and sedition because of the fitnah-sāzì of the narrow-minded ones and the solicitation of [Nūr Jahān]. ${ }^{253}$ This engendered a situation in the evening of Jahangir's reign where 'the parganahs of the mulk did not remain in the revenue system because of the bad management and treachery of tax collectors, and Qandahar șübah ... was lost from control and in some accounts the commander gave away the fort in accord with the will of [Nūr Jahān], and the people of the Deccan ... stopped obeying and having allied together extended [their] control over the southern mulk which had been conquered by Akbar, ${ }^{254}$ Shah Jahan managed to rectify these faults on succeeding his father. 'Routine government (nizām va nasaq) was restored and that which was in the revenue system was greatly advanced in quality and quantity', ${ }^{255}$ and 'the scattering of the era and the confusion of

243 Kt425; also Kt415-417, Kt430, Mt20r, Lt63v, Mj296v, Mj317r.

$244 \mathrm{Kt} 433$.

$245 \mathrm{Mj} 317 \mathrm{v}$.

246 Lt70r; also Lt122r.

247 Kt488; also Mj325r.

$248 \mathrm{Mj} 326 \mathrm{v}$.

249 Mj326v; also Kt498.

250 Lt75v, Mt25v.

251 Lt75v.

252 Mt25v.

$253 \mathrm{Kt} 657$.

254 Lt77v; also Kt671, Lt78v, Mt26v-27r.

255 Lt78v-79r; also Mt27r. 
the provinces found order anew. ${ }^{256}$ But it was not a permanent settlement. Divisions come to light once again towards the end of Shah Jahan's reign. His illness and subsequent disappearance from view were taken to mean that he was no longer alive and that effective rule was now Dārā Shikoh's. 'Great confusion befell the provinces of the empire. The corrupt in every corner and side, and the rebels in every șübah and sarkār, fostered revolt and sedition. ${ }^{257}$ Though Aurangzeb proved victorious in the subsequent war of succession, Hindustan continued to harbour 'untrustworthy hypocrites', 258 and dealing with them occupied much of his time as padshah. He is portrayed as doing so with resolve, and that eventually bore fruit. By the close of the seventeenth century, Aurangzeb's focus on 'repairing the ruins of the world' resulted in 'two-thirds of Hindustan cultivated and completely flourishing,. ${ }^{259}$ As for 'the few who still [do harm, they] live in mountains and isolated places ... like a mouse in a cave and a desert creeper, ${ }^{260}$

\section{Conclusion}

Analytically, the reasoning of the histories discussed above operates on two distinct levels: that of the imperial regime (saltanat) and that of the imperial polity (mamālik-i mahrūsah). In this picture, the Mughal empire straddled both levels. The substance of the regime was located in the metropolitan heartlands of Hindustan and the empire's centripetal institutions, whereas the polity embraced the interface between the empire's ruling elites and the general population. As articulated by the authors, these two levels were associated with two main problems: those of loyalty and unity. Loyalty to the Mughal dispensation was addressed primarily in relation to the imperial regime. Unity of the Mughal world was addressed primarily in relation to the imperial polity. These two problems are made pivotal, albeit in different ways, to each of the major topics covered in the four histories: Babur's emergence and conquest of Hindustan; the rivalry between Humayun and his brothers, followed by his exile in Safavid Iran and eventual restoration; the conflict pitching the Suris against the Mughals, and the enduring achievements of the Suri interregnum; Bairām Khān's regency and Akbar's move to take personal control of the levers of power; Jahangir's disavowal of affairs of state and effective rule by Nūr Jahān's clique at court; recovery and consolidation under Shah Jahan; the struggle for succession between Shah Jahan's sons, concluding with Aurangzeb's victory; and territorial expansion in all directions, earlier in and around Hindustan, later in the Deccan.

The problems of loyalty and unity are marshalled as especially pressing or significant in the authors' efforts to make sense of the details of the Mughal

256 Kt677-678.

257 Kt679; also Lt96v.

258 Lt115v.

$259 \mathrm{Mj} 380 \mathrm{v}$.

$260 \mathrm{Mt} 46 \mathrm{r}$. 
past. ${ }^{261}$ Those efforts justify the structuring of this article. Its two central sections make explicit the lineaments of the shared interpretive framework within which the authors rationalized their histories. That framework expresses a political sociology of empire which, because of the authors' intimacy with Mughal officialdom, was very likely held in common by ruling elites of the time. Furthermore, awareness of this framework unlocks for us the noteworthy solutions proposed, attempted, or enacted to the most acute problems confronted by the Mughals. Taken together, these solutions, and the changes to them over time, enable us to reconstruct the developments generally apprehended as consequential in the past, and thus how the overall trajectory of Mughal history was understood from the standpoint of Mughal paramountcy in around 1700.

This trajectory is historiographically distinctive. Unlike influential accounts of the Mughal past composed before and after (down to today), the authors of the histories analysed here do not accord Akbar or his reign exceptional importance. ${ }^{262}$ Certainly, there is no indication of Akbar as the greatest ruler in the dynasty, nor is there any indication that the padshahs who followed were overshadowed by him. Compared with earlier and later mainstream accounts, the Mughal past is interpreted in a more capacious and balanced manner. Rather than dwell on their purported virtues (strengths) and vices (weaknesses), ${ }^{263}$ the authors sought to communicate the significance of each of the padshahs and their reigns-including that of the Suris-over the whole of the period covered. This encouraged, if not compelled, them to take a longue durée perspective on the Mughal past. By the same token, to render meaningful their resulting narrative, a central thread was a sine qua non.

261 Few, if any, of the details of the histories are unknown to modern scholarship. All the individuals, events, ideas, and practices noted are documented in the scholarly literature. That information is distilled in the two most complete one-volume studies of the Mughal empire to date, namely, for political-military aspects, Ramesh C. Majumdar et al. (eds), The Mughal Empire (3rd edn, Bombay, 1994 [1974]) and, for socio-economic and administrative aspects, Irfan Habib, The Agrarian System of Mughal India, 1556-1707 (3rd edn, New Delhi, 2013 [1963]).

262 On the historiographical centrality of Akbar and his reign, see Saiyid Athar Abbas Rizvi, Religious and Intellectual History of the Muslims in Akbar's Reign (New Delhi, 1975); Harbans Mukhia, Historians and Historiography during the Reign of Akbar (New Delhi, 1976); Habib (ed.), Akbar and His India. Synthetic histories of the Mughal empire continue to make Akbar and his reign the basis of their narrative, with later developments an extension or reaction to them. Well-known examples include John F. Richards, The Mughal Empire (Cambridge, UK, 1993); Harbans Mukhia, The Mughals of India (Oxford, 2004).

263 This is a characteristic of much Indian and European historiography (and commentary) on the Mughal empire from the early eighteenth to the late twentieth centuries. See Zahiruddin Malik, 'Persian historiography in India during the 18th century', in Mohibbul Hasan (ed.), Historians of Medieval India (Meerut, 1968), pp. 149-163; Waseem (ed.), Development of Persian Historiography in India; Kumkum Chatterjee, 'History as self-representation: The recasting of a political tradition in late eighteenth-century eastern India', Modern Asian Studies 32:4 (1998), pp. 913-948; Muhammad Aslam Syed, Muslim Responses to the West: Muslim Historiography in India, 1857-1914 (Islamabad, 1988); Christopher A. Bayly, 'Modern Indian historiography', in Michael Bentley (ed.), Companion to Historiography (London, 1997), pp. 677-691. 
And if we look, there is, indeed, a central thread running through the histories. It is spun from two main strands. One is constituted by the umarā'strata of the ruling elites. Beginning with Babur's conquest, the umarā' provided the continuity between one reign and the next-and also between dynasties. With each accession, what the authors call 'the old umarā' were, as a rule, reincorporated into the regime in concert with the incorporation of freshly minted umara $\bar{a}$. Thereby the body of the ruling elites was at once reaffirmed and revitalized. The other strand in the central thread is constituted by Hindustan. This area is core to, and a constant in, the authors' narrative. Within Hindustan, the histories stress, over all others, the storied capitals of Agra and Delhi; the myriad of topics are ultimately recounted in relation to this heartland area. That is why the rule of the Suris, who had a base in Delhi, are treated as an integral component of the Mughal past. This is at variance with the practice of modern scholars who have tended to marginalize or ignore the broader influence of Suri rule.

The course charted by the central thread is in essence a superposition of two distinct trends. The first is cyclical, repeatedly moving between order and disorder. In general, the histories impart the image of the end or start of each reign being marked by an increase in disorder, typically in the form of rebellions or uprisings against Mughal rule or the oppression of Mughal subjects. Each new padshah and his elites were in time able to eradicate, suppress, or tame their opponents, and so re-establish order in the empire. There then ensued a period of stability and tranquillity, at least in the metropolitan heartlands, during which reforms were introduced and the regime reconsolidated to facilitate ongoing Mughal rule and the ease and prosperity of ordinary people. These intervening periods are remarked upon for productive, fruitful developments, above all in the domains of revenue, justice, bureaucracy, communication, and transport.

This last point gestures to the second trend which crosscuts the cyclical in the authors' interpretation of the Mughal past. The second trend is secular in quality, narrating the progressive centralization of the imperial regime. Its beginnings, however, were hardly auspicious. Well before his famed conquests, Sher Shah observed the manner of Babur's rule and was reportedly unimpressed by what he saw. 'The Mughals do not work themselves. They are busy hunting and feasting and indulging in pleasures. The actual work is done by the ministers.' It would thus be 'easy to remove the Mughals from Hindustan'. ${ }^{264}$ That, however, is no longer the case after Humayun's restoration. Henceforth, the empire is depicted as increasingly centralized, in a monotonic process continuously elaborated through to Aurangzeb's reign and the authors' present. Several developments bear witness to this. There is little or no connection between the frequently used terms daulat and saltanat in the histories. Daulat is mostly invoked in the narrow sense of divinely or cosmically imbued 'fortune' or 'luck' (synonymous with iqbāl and țālic). ${ }^{265}$ That is in stark contrast with the practice earlier in the seventeenth century, when both terms were often

265 of the four histories, only Lubb al-tawārikh uses the term-and that occasionally-in the other senses which have sovereign connotations. 
used as major attributes of sovereign governance. ${ }^{266}$ This change in meaning suggests that conceptions of sovereign governance became increasingly mundane and temporal-de-cosmofied-as the century passed. The authors document padshahs regularly calling formal assemblies of the ruling elites in order to seek their counsel (kangāsh, mashvarat) before making fateful decisions. This practice vanishes, however, in Akbar's reign and thereafter does not recur in the histories. For the entirety of the Mughal past, the authors openly display awareness of the significance of plurality within the imperial polity, defined in particular by ethnicity, doctrine, and tradition. That plurality is viewed as a severe challenge in the first three reigns, from Babur to Akbar. Over these reigns, there was purposeful intermingling of ruling elites drawn from different religious backgrounds, retrospectively buttressed by the ideology of 'universal peace' (șulh-i kull). But as intermingling proceeded apace, plurality fades as a challenge. Its place in the histories is taken by opposition to the padshah defined not in terms of ethnicity, doctrine, or tradition, but in terms of those who were reconcilable or irreconcilable with the empire. ${ }^{267}$ In parallel, the scope of those whom the Mughals deemed as having a plausible claim on the throne narrowed in time from members of the extended dynastic family (including brothers of the incumbent ruler) to solely the sons of the reigning padshah. These developments, taken in the round, cohere with the thesis that contemporaries were conscious of a broad, long-term trend in which Mughal rule became noticeably more hierarchical, absolutist, and worldly as one padshah succeeded another. ${ }^{268}$

The authors do not limit the secular trend to centralization of the Mughal regime. It is also visible in the territorial expansion of the imperial polity. Aurangzeb is eulogized for his peerless devotion to 'improving and expanding the empire', which 'made the padshahs of the region pay heed [to him] and revealed to people that the meaning of [him being] the Lord of the Conjuncture is taking and holding the world, ${ }^{269}$ This resonates with the idea

266 Earlier Mughal usages of daulat and saltanat are discussed in Sood, 'Knowledge of the art of governance', pp. 265-268, 280-282.

267 This perspective differs markedly from the Muslim-Hindu dichotomy which became so prevalent in historiography from the nineteenth century. On the shift in perspectives, see Harbans Mukhia, 'Communalism and the writing of medieval Indian history', in his Perspectives on Medieval History, pp. 33-45.

268 The thesis bears comparison with developments occurring elsewhere in Eurasia's complex polities in early modern times, which have been debated over the past generation mainly in relation to multiple modernities and the Great Divergence. See Joseph F. Fletcher, Jr, 'Integrative history: parallels and interconnections in the early modern period, 1500-1800', Journal of Turkish Studies 9 (1985), pp. 37-57; Victor Lieberman (ed.), Beyond Binary Histories: Re-Imagining Eurasia to c. 1830 (Ann Arbor, MI, 1999); Special Issue on 'Early Modernities', Daedalus 127:3 (1998); Special Issue on 'Modernity', Journal of the Economic and Social History of the Orient 40:4 (2007); Jean-Laurent Rosenthal and R. Bin Wong, Before and Beyond Divergence: The Politics of Economic Change in China and Europe (Cambridge, MA, 2011); Shami Ghosh, 'The "Great Divergence," politics, and capitalism', Journal of Early Modern History 18:6 (2014), pp. 1-43.

269 Lt116r. The epithet Șăhib-Qirāni is translated here as 'the Lord of the Conjuncture'. However, it was also commonly understood by Mughals of the period as a reference to Timur or to those in his line of descent. For further details, see fn. 61. 
that expansion by conquest was a highly desirable, if not obligatory, pursuit of rulers if they wished posterity to memorialize them as great. Early Mughal expansion is acknowledged as having been aided by alliances with foreign rulers and their elites. But the more important and enduring driver was conflict, generally unintended, with opponents. The authors' attitude is that, beyond the metropolitan heartlands, the Mughals preferred to govern with a light touch if possible, via autonomous, tributary local rulers. This proved possible where opponents were potentially reconcilable and thus amenable to reincorporation within the pre-existing body politic. But for those who were irreconcilable, such as Afghan communities in the north and northwest and the Marathas in the Deccan, a different fate was in store. Military campaigns against them resulted in more of their territories being assimilated into the machinery of sovereign administration, and their revenue system being increasingly directed from the imperial capitals. So it was that the empire grew to embrace Gujarat, Kashmir, Bengal, and the Deccan, culminating with Aurangzeb's conquest of Bijapur and Golconda-and the making of Mughal paramountcy.

Acknowledgements. I am very grateful to Marc D. Baer, Antony M. Best, John R. A. Cleaver, David R. Gagie, Adeel Khan, and Brooks Prouty for their comments on earlier versions of this article.

Competing interests. None.

\section{Appendix 1: Glossary of Persian terms}

\begin{tabular}{|c|c|}
\hline $\operatorname{din}$ & religion; spiritual tradition; contrast with mashrab (q.v.) and mazhab (q.v.) \\
\hline farmān-ravā & entitled to command; monarch; ruler; title inferior to pādshāh (q.v.) \\
\hline fitnah, fasād & $\begin{array}{l}\text { sedition, mischief; often found together in the canonical form fitnah } \\
\text { va fasād }\end{array}$ \\
\hline ḥākim & $\begin{array}{l}\text { governor; commander; appointed by, and subservient to, a } \\
\text { higher-level ruler }\end{array}$ \\
\hline jāgìr & $\begin{array}{l}\text { right (in principle temporary) conferred by a ruler on an official to } \\
\text { collect specified taxes from revenue-producing lands }\end{array}$ \\
\hline mamlakat, pl. mamālik & possession; realm; country; province; contrast with salțanat (q.v.) \\
\hline mamālik-i mahrūsah & $\begin{array}{l}\text { 'protected' or 'guarded' countries or provinces under imperial } \\
\text { hegemony }\end{array}$ \\
\hline manșab & $\begin{array}{l}\text { rank, status, and position defined by number(s) and title; a core } \\
\text { element of the calibrated hierarchy formally instituted by the } \\
\text { Mughals in 1574-1575 }\end{array}$ \\
\hline manșabdār & holder of manșab (q.v.) \\
\hline mashārib, s. mashrab & dispositions; humours; generally narrower in scope than din (q.v.) \\
\hline mazāhib, s. mazhhab & $\begin{array}{l}\text { doctrines; modes of conduct; generally narrower in scope than din } \\
\text { (q.v.) }\end{array}$ \\
\hline mulk & possession; realm; country; kingdom; contrast with salțanat (q.v.) \\
\hline
\end{tabular}




\begin{tabular}{|c|c|}
\hline nāmūs & honour; dignity; law \\
\hline pādshāh (padshah) & emperor; great king \\
\hline parganah & $\begin{array}{l}\text { rural area delineated for revenue and administrative purposes; } \\
\text { subdivision of sarkār (q.v.) }\end{array}$ \\
\hline pishkish & tribute paid to a superior \\
\hline rāi, rājā (raja), rānā & $\begin{array}{l}\text { titles normally associated with a Hindu (non-Muslim) chief, prince or } \\
\text { ruler; rānā was favoured in particular by the Rajputs }\end{array}$ \\
\hline salțanat & $\begin{array}{l}\text { power; authority; dominion; majesty; governance; regime; empire; } \\
\text { generally superior to mamlakat (q.v.), mulk (q.v.), and viläyat (q.v.) }\end{array}$ \\
\hline sulțān (sultan) & monarch; king; emperor; ruler exercising salțanat (q.v.) \\
\hline sarkār & $\begin{array}{l}\text { subdivision of șūbah (q.v.), usually encompassing contiguous } \\
\text { parganahs (q.v.); establishment of a member of the ruling elites }\end{array}$ \\
\hline șūbah & largest division of the empire; province; grouping of sarkārs (q.v.) \\
\hline umarā', s. amīr & officials of high rank and status; courtiers; grandees \\
\hline vālī & governor; prince; ruler; title inferior to pādshāh (q.v.) \\
\hline vilāyat & possession; realm; country; government; contrast with salțanat (q.v.) \\
\hline zamīndār & $\begin{array}{l}\text { local elite or notable, often hereditary, with varied claims on the } \\
\text { produce of land and/or land revenue; landlord or landholder } \\
\text { directly controlling peasants }\end{array}$ \\
\hline
\end{tabular}

Sources: Muhammad Baqā’, Mir’āt-i jahān-numā; Vindrāvandās, Lubb al-tawārīkh; Sujān Rāi, Khulāṣat al-tawārīkh; Jagjīvāndās, Muntakhab al-tawārikk; Habib, The Agrarian System; Richards, The Mughal Empire.

\section{Appendix 2: Table of birth, death, and regnal dates of principal rulers}

\begin{tabular}{llll}
\hline Ruler & Birth & Death & Reign \\
\hline Akbar & 1542 & 1605 & $1556-1605$ \\
\hline Aurangzeb & 1618 & 1707 & $1658-1707$ \\
\hline Babur & 1483 & 1530 & $1526-1530$ \\
\hline Humayun & 1508 & 1556 & $1530-1540$ \& 1555-1556 \\
\hline Jahangir & 1569 & 1627 & $1605-1627$ \\
\hline Shah Jahan & 1592 & 1666 & $1627-1658$ \\
\hline Sher Shah & circa 1486 & 1545 & $1538-1545$ \\
\hline
\end{tabular}

Source: Majumdar et al. (eds), The Mughal Empire.

Cite this article: Sood, Gagan D. S.. 2022. 'A political sociology of empire: Mughal historians on the making of Mughal paramountcy '. Modern Asian Studies 56 (4), pp. 1253-1294. https://doi.org/ $10.1017 /$ S0026749X21000378 